\title{
Isotopic constraints on the role of hypohalous acids in sulfate aerosol formation in the remote marine boundary layer
}

\author{
Qianjie Chen $^{1}$, Lei Geng ${ }^{1, a, b}$, Johan A. Schmidt ${ }^{2}$, Zhouqing Xie ${ }^{3}$, Hui Kang ${ }^{3}$, Jordi Dachs ${ }^{4}$, Jihong Cole-Dai ${ }^{5}$, \\ Andrew J. Schauer ${ }^{6}$, Madeline G. Camp ${ }^{7, c}$, and Becky Alexander ${ }^{1}$ \\ ${ }^{1}$ Department of Atmospheric Sciences, University of Washington, Seattle, WA, USA \\ ${ }^{2}$ Department of Chemistry, University of Copenhagen, Copenhagen, Denmark \\ ${ }^{3}$ Institute of Polar Environments, School of Earth and Space Sciences, University of Science and Technology of China, \\ Hefei, Anhui, China \\ ${ }^{4}$ Department of Environmental Chemistry, IDAEA-CSIC, IDAEA-CSIC, Barcelona, Catalunya, Spain \\ ${ }^{5}$ Department of Chemistry and Biochemistry, South Dakota State University, Brookings, SD, USA \\ ${ }^{6}$ Department of Earth and Space Sciences, University of Washington, Seattle, WA, USA \\ ${ }^{7}$ Joint Institute for the Study of Atmosphere and Ocean, University of Washington, Seattle, WA, USA \\ ${ }^{a}$ now at: Univ. Grenoble-Alpes, LGGE, 38000, Grenoble, France \\ ${ }^{b}$ now at: CNRS, LGGE, 38000, Grenoble, France \\ ${ }^{\mathrm{c}}$ now at: DSG Solutions, LLC, Shoreline, WA, USA
}

Correspondence to: Becky Alexander (beckya@atmos.washington.edu)

Received: 10 May 2016 - Published in Atmos. Chem. Phys. Discuss.: 12 May 2016

Revised: 24 August 2016 - Accepted: 24 August 2016 - Published: 14 September 2016

\begin{abstract}
Sulfate is an important component of global atmospheric aerosol, and has partially compensated for greenhouse gas-induced warming during the industrial period. The magnitude of direct and indirect radiative forcing of aerosols since preindustrial times is a large uncertainty in climate models, which has been attributed largely to uncertainties in the preindustrial environment. Here, we report observations of the oxygen isotopic composition $\left(\Delta^{17} \mathrm{O}\right)$ of sulfate aerosol collected in the remote marine boundary layer (MBL) in spring and summer in order to evaluate sulfate production mechanisms in pristine-like environments. Model-aided analysis of the observations suggests that $33-50 \%$ of sulfate in the MBL is formed via oxidation by hypohalous acids $(\mathrm{HOX}=\mathrm{HOBr}+\mathrm{HOCl})$, a production mechanism typically excluded in large-scale models due to uncertainties in the reaction rates, which are due mainly to uncertainties in reactive halogen concentrations. Based on the estimated fraction of sulfate formed via HOX oxidation, we further estimate that daily-averaged HOX mixing ratios on the order of $0.01-0.1$ parts per trillion (ppt $=\mathrm{pmol} / \mathrm{mol}$ ) in the remote $\mathrm{MBL}$ during spring and summer are sufficient to explain the observations.
\end{abstract}

\section{Introduction}

Large uncertainties in estimates of aerosol radiative forcing, especially those induced by sulfate aerosol and its interaction with clouds, have significantly impeded the progress of constraining the magnitude of anthropogenic radiative forcing since preindustrial times (Myhre et al., 2013). The aerosol radiative forcing uncertainties are attributed in large part to our poor understanding of the abundance of natural aerosols, especially sulfate aerosol in the marine boundary layer (MBL) (Carslaw et al., 2013) that is mainly produced from the oxidation of dimethylsulfide (DMS) emitted from oceanic phytoplankton (Bates et al., 1992). The radiative effects of sulfate involve scattering of solar radiation and modification of cloud properties (Haywood and Boucher, 2000). Determining the magnitude of these radiative effects requires in part understanding of sulfate formation mechanisms. Only sulfate formed via gas-phase oxidation can nucleate new particles (Kerminen et al., 2010; Kulmala et al., 2000), with implications for particle number density. Sulfate formed in the aqueous phase impacts particle growth rates in clouds, with implications for aerosol size distribution (Lelieveld and Heintzenberg, 1992). 
In the MBL, due to the high solubility and fast aqueousphase oxidation of $\mathrm{SO}_{2}$, the main sulfate production mechanisms are thought to be in-cloud oxidation of dissolved $\mathrm{SO}_{2}\left(\mathrm{~S}(\mathrm{IV})=\mathrm{SO}_{2} \cdot \mathrm{H}_{2} \mathrm{O}+\mathrm{HSO}_{3}^{-}+\mathrm{SO}_{3}^{2-}\right)$ by hydrogen peroxide $\left(\mathrm{H}_{2} \mathrm{O}_{2}\right)$ and ozone $\left(\mathrm{O}_{3}\right)$ (Faloona, 2009; Alexander et al., 2012). In addition to sulfate formation in clouds, MBL sulfate formation can occur via oxidation of $\mathrm{SO}_{2}$ by $\mathrm{OH}$ in the gas phase (Stockwell and Calvert, 1983) and on the surface of sea-salt aerosols in the presence of $\mathrm{O}_{3}$ (Sievering et al., 2004; Alexander et al., 2005). Other sulfate production mechanisms that are important in specific environments, such as metal-catalyzed oxidation of $\mathrm{S}(\mathrm{IV})$ by $\mathrm{O}_{2}$ (Alexander et al., 2009; Harris et al., 2013, 2014) and gas-phase oxidation of $\mathrm{SO}_{2}$ by Criegee intermediates (Mauldin III et al., 2012; Pierce et al., 2013), are thought to be minor in the MBL.

Modeling studies by Vogt et al. (1996) attributed a large part $(60 \%)$ of aqueous-phase sulfate production in the MBL to oxidation of S(IV) by hypohalous acids $(\mathrm{HOX}=\mathrm{HOBr}+\mathrm{HOCl})$. Furthermore, von Glasow et al. (2002) evaluated the contribution of HOX to sulfate formation in both the cloud-free and cloudy MBL with a numerical one-dimensional model. Under both cloud-free and cloudy MBL conditions, about $30 \%$ of sulfate was formed via oxidation of S(IV) by HOX in the aqueous phase. Despite the potentially important role of HOX in sulfate formation in the MBL, the "S(IV) + HOX" reaction has not been included in most large-scale models of sulfur chemistry due to large uncertainties in (1) rate constants for reactions between HOX and $\mathrm{HSO}_{3}^{-}$, (2) the Henry's law constant for $\mathrm{HOCl}\left(\mathrm{H}_{\mathrm{HOCl}}\right)$ and $\mathrm{HOBr}\left(H_{\mathrm{HOBr}}\right)$, and (3) concentrations of $\mathrm{HOX}$ in the MBL.

Laboratory experiments demonstrate that reactions between $\mathrm{HOX}$ and $\mathrm{SO}_{3}^{2-}$ occur via nucleophilic attack of $\mathrm{SO}_{3}^{2-}$ onto the $\mathrm{X}$ atom of $\mathrm{HOX}(\mathrm{X}=\mathrm{Br}$ or $\mathrm{Cl})$, followed by rapid hydrolysis of $\mathrm{XSO}_{3}^{-}$(Yiin and Margerum, 1988; Fogelman et al., 1989; Troy and Margerum, 1991):

$\mathrm{HOX}+\mathrm{SO}_{3}^{2-} \rightarrow \mathrm{OH}^{-}+\mathrm{XSO}_{3}^{-}$,

$\mathrm{XSO}_{3}^{-}+\mathrm{H}_{2} \mathrm{O} \rightarrow \mathrm{SO}_{4}^{2-}+\mathrm{X}^{-}+2 \mathrm{H}^{+}$.

The rate constants for the " $\mathrm{HOBr}+\mathrm{SO}_{3}^{2-, "}\left(k_{\mathrm{HOBr}}+\mathrm{SO}_{3}^{2-}\right)$ and " $\mathrm{HOCl}+\mathrm{SO}_{3}^{2-}$ " $\left(k_{\mathrm{HOCl}}+\mathrm{SO}_{3}^{2-}\right)$ reactions are $5 \times 10^{9}$ and $7.6 \times 10^{8} \mathrm{M}^{-1} \mathrm{~s}^{-1}$, respectively (Fogelman et al., 1989; Troy and Margerum, 1991). In addition, Liu (2000) suggested that the reaction of $\mathrm{HOBr}$ with $\mathrm{HSO}_{3}^{-}$follows a similar pathway as with $\mathrm{SO}_{3}^{2-}$, but with a lower reaction rate constant due to reduced nucleophilicity of $\mathrm{HSO}_{3}^{-}$compared to $\mathrm{SO}_{3}^{2-}$ :

$\mathrm{HOBr}+\mathrm{HSO}_{3}^{-} \rightarrow \mathrm{H}_{2} \mathrm{O}+\mathrm{BrSO}_{3}^{-}$,

$\mathrm{BrSO}_{3}^{-}+\mathrm{H}_{2} \mathrm{O} \rightarrow \mathrm{SO}_{4}^{2-}+\mathrm{Br}^{-}+2 \mathrm{H}^{+}$.

They were unable to obtain $k_{\mathrm{HOBr}+\mathrm{HSO}_{3}^{-}}$from their laboratory experiments due to interference from the unavoidable reaction of $\mathrm{HOBr}$ with $\mathrm{Br}^{-}$in acidic solution. Based on their laboratory results, they suggested an upper limit for $k_{\mathrm{HOBr}+\mathrm{HSO}_{3}^{-}}\left(<3.2 \times 10^{9} \mathrm{M}^{-1} \mathrm{~s}^{-1}\right)$. To the best of our knowledge, there is no laboratory experiment that determined the reaction rate constant of $\mathrm{HOCl}$ with $\mathrm{HSO}_{3}^{-}$

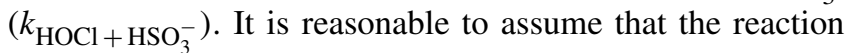
of $\mathrm{HOCl}$ with $\mathrm{HSO}_{3}^{-}$follows a similar pathway as the reaction of $\mathrm{HOBr}$ with $\mathrm{HSO}_{3}^{-}$(Eqs. 3-4). Lack of knowledge of $k_{\mathrm{HOBr}}+\mathrm{HSO}_{3}^{-}$and $k_{\mathrm{HOCl}}+\mathrm{HSO}_{3}^{-}$leads to large uncertainties in calculations of the sulfate formation rate from HOX because $\mathrm{HSO}_{3}^{-}$is the dominant $\mathrm{S}(\mathrm{IV})$ species $(>93 \%)$ in clouds at typical cloud $\mathrm{pH}$ between 3 and 6 (Faloona, 2009).

Laboratory measurements of $H_{\mathrm{HOCl}}$ range from 470 to $910 \mathrm{M} \mathrm{atm}^{-1}$ (Holzwarth et al., 1984; Hanson and Ravishankara, 1991; Blatchley III et al., 1992). Based on the aforementioned laboratory results, Huthwelker et al. (1995) suggested an expression for $\mathrm{H}_{\mathrm{HOCl}}$ as a function of $\mathrm{H}_{2} \mathrm{SO}_{4}$ concentration and temperature. By assuming a temperature of $298.15 \mathrm{~K}$ and pure water, Sander et al. (2006) suggested $H_{\mathrm{HOCl}} \approx 650 \mathrm{M} \mathrm{atm}^{-1}$. Estimates of $H_{\mathrm{HOBr}}$ show a much larger range from 93 to $6100 \mathrm{M} \mathrm{atm}^{-1}$ (McCoy et al., 1990; Blatchley III et al., 1992; Vogt et al., 1996; Frenzel et al., 1998; Sander, 2015; Sander et al., 2006). $H_{\mathrm{HOBr}}=$ $93 \mathrm{M} \mathrm{atm}^{-1}$ was assumed in the modeling studies by Vogt et al. (1996) and von Glasow et al. (2002), who simply estimated $\mathrm{H}_{\mathrm{HOBr}}$ as $10 \%$ of the solubility constant of $\mathrm{HOCl}$ at $293 \mathrm{~K}$ from Huthwelker et al. (1995). Frenzel et al. (1998) estimated $H_{\mathrm{HOBr}}$ to be $6100 \mathrm{M} \mathrm{atm}^{-1}$ using the Gibbs free energy of $\mathrm{HOBr}$. Blatchley III et al. (1992) estimated $H_{\mathrm{HOBr}}$ to be at least twice the Henry's law constant of $\mathrm{HOCl}$ that was measured in their laboratory experiments. Based on this relationship, Sander et al. (2006) extrapolated $H_{\mathrm{HOBr}}$ to be $\geq 1300 \mathrm{M} \mathrm{atm}^{-1}$ using $H_{\mathrm{HOCl}}$ from Huthwelker et al. (1995). Only McCoy et al. (1990) measured $H_{\mathrm{HOBr}}$ from laboratory experiments and reported $H_{\mathrm{HOBr}}$ to be about $1900 \mathrm{M} \mathrm{atm}^{-1}$.

Observations of HOX concentrations in the troposphere are sparse. Liao et al. (2012) made the first direct observation of $\mathrm{HOBr}$ in Alaska in spring 2009, and reported average daytime surface mixing ratios of about $10 \mathrm{ppt}$, consistent with the active bromine $\left(\mathrm{HOBr}+\mathrm{Br}_{2}\right)$ mixing ratios measured by Neuman et al. (2010). HOBr mixing ratios were below their detection limit of 2 ppt at night (Liao et al., 2012). The only direct observation of a $\mathrm{HOCl}$ mixing ratio was made over the eastern tropical Atlantic at the surface during June 2009 and a large range from $<5$ to $173 \mathrm{ppt}$ was reported (Lawler et al., 2011). The detection limit of $\mathrm{HOCl}$ in Lawler et al. (2011) was 5 ppt.

The $\Delta^{17} \mathrm{O}\left(\approx \delta^{17} \mathrm{O}-0.52 \delta^{18} \mathrm{O}\right)$ of sulfate is solely dependent upon the relative importance of the oxidants involved in its formation (Savarino et al., 2000), and thus provides an observational constraint for sulfate formation pathways (Lee and Thiemens, 2001; Lee et al., 2001; Jenkins and Bao, 2006; McCabe et al., 2006; Patris et al., 2007; Dominguez et al., 2008; Alexander et al., 2005, 2009, 2012). $\delta^{17} \mathrm{O}$ or $\delta^{18} \mathrm{O}$ is 
Table 1. $\Delta^{17} \mathrm{O}$ of sulfate produced via different pathways.

\begin{tabular}{lll}
\hline Sulfate formation pathway & $\Delta^{17} \mathrm{O}\left(\mathrm{nssSO}_{4}^{2-}\right)(\% \circ)$ & References \\
\hline $\mathrm{SO}_{2}(\mathrm{~g})+\mathrm{OH}$ & 0 & Dubey et al. (1997), Lyons (2001) \\
$\mathrm{S}(\mathrm{IV})+\mathrm{H}_{2} \mathrm{O}_{2}$ & 0.7 & Savarino and Thiemens (1999) \\
$\mathrm{S}(\mathrm{IV})+\mathrm{O}_{3}$ & 6.5 & Vicars and Savarino (2014) \\
$\mathrm{S}(\mathrm{IV})+\mathrm{O}_{2}$ & -0.09 & Barkan and Luz (2005) \\
$\mathrm{S}(\mathrm{IV})+\mathrm{HOX}$ & 0 & Fogelman et al. (1989), Troy and Margerum (1991) \\
\hline
\end{tabular}

expressed as

$\delta^{x} \mathrm{O}=\frac{R_{\mathrm{SA}}^{x}}{R_{\text {VSMOW }}^{x}}-1$,

where $R_{\mathrm{SA}}^{x}$ is the ${ }^{x} \mathrm{O} /{ }^{16} \mathrm{O}$ ratio of the sample, $R_{\mathrm{VSMOW}}^{x}$ is the same ratio of Vienna Standard Mean Ocean Water (VSMOW) (Gonfiantini et al., 1993), and $x=17$ or 18 . The $\Delta^{17} \mathrm{O}$ value is expressed in unit of per mill (\%o). Table 1 lists the $\Delta^{17} \mathrm{O}$ of sulfate formed via different pathways. $\Delta^{17} \mathrm{O}$ of sulfate produced from $\mathrm{OH}, \mathrm{H}_{2} \mathrm{O}_{2}$, and metal-catalyzed $\mathrm{O}_{2}$ oxidation pathways are 0\%o (Dubey et al., 1997; Lyons, 2001), 0.7\%o (Savarino and Thiemens, 1999), and $-0.09 \%$ o (Barkan and Luz, 2005), respectively, which were discussed in detail in Alexander et al. (2005, 2009) and Sofen et al. (2011) and will not be repeated here. Primary anthropogenic sulfate has a $\Delta^{17} \mathrm{O}$ of $0 \%$ (Lee et al., 2002). Sulfate produced from $\mathrm{O}_{3}$ oxidation has a $\Delta^{17} \mathrm{O}$ of $6.5 \%$, assuming $\Delta^{17} \mathrm{O}\left(\mathrm{O}_{3}\right)=26 \%$ (Vicars and Savarino, 2014). $\Delta^{17} \mathrm{O}$ of sulfate produced from HOX oxidation has not been directly determined from laboratory experiments. Since HOX promotes sulfate formation via " $\mathrm{SO}_{3}^{2-}+\mathrm{HOX}^{-}$" reactions by adding one oxygen atom from $\mathrm{H}_{2} \mathrm{O}$ to sulfate instead of transferring its own oxygen atom (Fogelman et al., 1989; Troy and Margerum, 1991; Yiin and Margerum, 1988), the $\Delta^{17} \mathrm{O}$ of sulfate produced from " $\mathrm{SO}_{3}^{2-}+\mathrm{HOX}^{2}$ " reactions is expected to have the same $\Delta^{17} \mathrm{O}$ as water $(0 \%$ ) (Gonfiantini et al., 1993). Liu (2000) suggests the reaction of $\mathrm{HOBr}$ with $\mathrm{HSO}_{3}{ }^{-}$follows a similar pathway as with $\mathrm{SO}_{3}{ }^{2-}$ (Eqs. 1-2), resulting in $\Delta^{17} \mathrm{O}$ of $0 \%$ for sulfate produced via this reaction. We assume that the reaction of $\mathrm{HOCl}$ with $\mathrm{HSO}_{3}^{-}$follows a similar pathway as the reaction of $\mathrm{HOBr}$ with $\mathrm{HSO}_{3}^{-}$ (Eqs. 3-4) and produces sulfate with $\Delta^{17} \mathrm{O}$ of $0 \%$. Based on these mechanistic studies, the $\Delta^{17} \mathrm{O}$ of sulfate produced from HOX oxidation is expected to be $0 \%$.

Here, we report observations of $\Delta^{17} \mathrm{O}$ of sulfate in atmospheric aerosols collected over a large spatial domain in the remote Southern Hemisphere MBL during spring and summer. We use these observations, combined with a global chemical transport model, to estimate the role of HOX in sulfate formation in the MBL.

\section{Sampling and measurements}

Aerosol samples were collected on quartz fiber filters (Whatman) using high-volume air samplers located at the front of the ships from two ship cruises: (1) "Malaspina" as part of the Malaspina Circumnavigation Campaign on board of RV Hespérides (González-Gaya et al., 2014), and (2) "Xue-Long" as part of the 28th China Antarctic Research Expedition supported by the the Program of China Polar Environment Investigation and Assessment (project no. CHINARE2011-2015) on board of the Xue Long icebreaker. The quartz filters were pre-combusted at $450{ }^{\circ} \mathrm{C}$ for $8 \mathrm{~h}$ and kept wrapped in aluminum foil and plastic ziplock bags before use. Most Xue Long filters were changed every $48 \mathrm{~h}$, while most Malaspina filters were changed every $24 \mathrm{~h}$. The sampler was connected to a wind direction vane to avoid contamination from the ship exhaust. After sampling, filters were kept wrapped in aluminum foil and plastic ziplock bags at $-20^{\circ} \mathrm{C}$. Blank filters were processed as field samples. One-quarter of each Xue Long filter and 1/8 of each Malaspina filter were sent to the University of Washington for isotope and concentration measurements. Our samples from the Malaspina campaign cover the track from Cádiz, Spain, to Sydney, Australia, via Rio de Janeiro, Brazil, Cape Town, South Africa, and Perth, Australia, between 2 January and 23 March 2011. The Xue Long campaign started from Shanghai, China, on 4 November 2011, traveling through Western Australia, Zhong Shan station, Antarctica, southern Argentina and back to Shanghai, China, following the original route, ending on 5 April 2012. Figure 1 shows the 5-day back trajectories calculated from the NOAA HYSPLIT model for all sampling locations (http://ready.arl.noaa. gov/HYSPLIT.php), which gives a broad picture of the origins of air parcels along our sampling track. Most of the air parcels arriving at our sampling locations were over the ocean for the previous 5 days $(\approx$ lifetime of sulfate, Chin et al., 2000), which suggests that the sulfate collected was mainly formed in the MBL. However, observations of polycyclic aromatic hydrocarbons (PAHs) during the Malaspina campaign suggest that samples collected over the subtropical Indian Ocean and Atlantic Ocean might have continental influence (González-Gaya et al., 2014).

Aerosol ion concentrations $\left(\mathrm{SO}_{4}^{2-}, \mathrm{NO}_{3}^{-}, \mathrm{Cl}^{-}, \mathrm{NH}_{4}^{+}, \mathrm{Na}^{+}\right.$, $\mathrm{K}^{+}, \mathrm{Mg}^{2+}, \mathrm{Ca}^{2+}$ ) for filter samples from the Malaspina and 


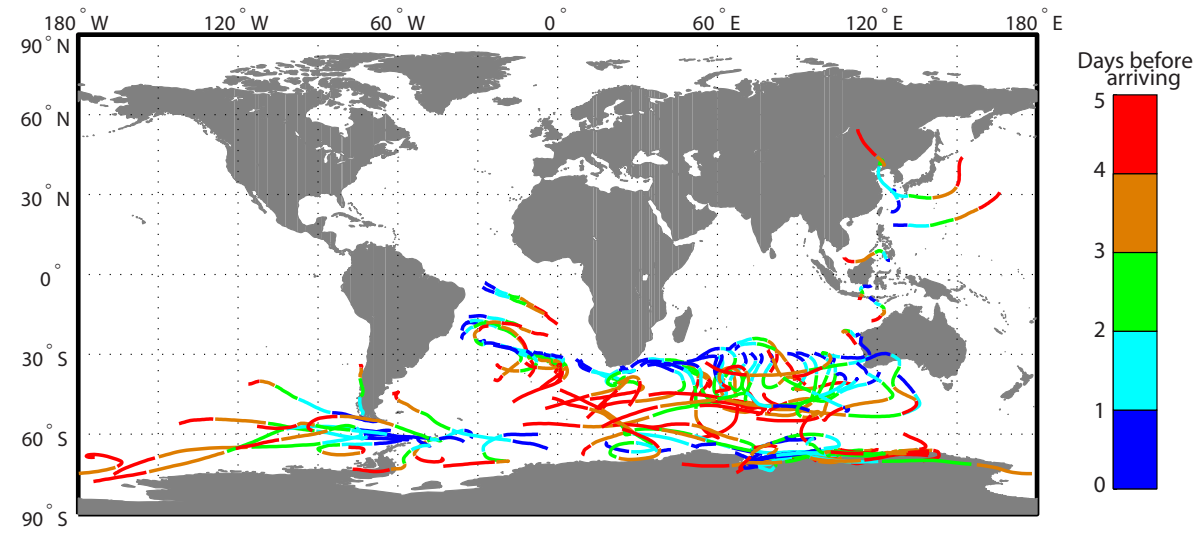

Figure 1. Five-day back trajectories calculated from the HYSPLIT model for all sampling locations. Blue indicates the ending point of each back trajectory.

Xue Long campaigns were measured at South Dakota State University (USA) and the University of Science and Technology of China (China), respectively. The analytical procedures for measurement of anions and cations using ion chromatography have been presented elsewhere (Cole-Dai et al., 1995; Jauhiainen et al., 1999). Typical instrumental analytical precision for all ions is better than $10 \%$ RSD (relative standard deviation) at the $\mu \mathrm{gL}^{-1}$ level. Bromide aerosol concentrations $\left(\left[\mathrm{Br}^{-}\right]\right)$were also measured for the Xue Long samples (Supplement). There is no relationship between observed $\mathrm{Br}^{-}$concentration and $\Delta^{17} \mathrm{O}\left(\mathrm{nssSO}_{4}^{2-}\right)$, nor with our calculated $[\mathrm{HOX}]_{\mathrm{g}}$ (not shown), because factors such as aerosol $\mathrm{pH}$, sunlight and oxidants play an important role in the acid-catalyzed formation of reactive halogens and removal of HOBr (Fickert et al., 1999; Schmidt et al., 2016). Similarly, there is no relationship between $\left[\mathrm{Br}^{-}\right]$and $\mathrm{HOBr}$ mixing ratios in the global modeling study by Schmidt et al. (2016) (not shown). Thus, $\left[\mathrm{Br}^{-}\right]$alone is not a good proxy for the "HOBr $+\mathrm{S}(\mathrm{IV})$ " reaction.

In the remote MBL, total sulfate consists of sea-salt sulfate $\left(\mathrm{ssSO}_{4}^{2-}\right)$ and non-sea-salt sulfate $\left(\mathrm{nssSO}_{4}^{2-}\right)$. $\mathrm{ssSO}_{4}^{2-}$ refers to primary sulfate emitted directly from seawater via the bursting of bubbles, while $\mathrm{nssSO}_{4}^{2-}$ refers to secondary sulfate produced from oxidation of $\mathrm{SO}_{2}$. For the Xue Long samples, the $\mathrm{nssSO}_{4}^{2-}$ fraction $\left(f_{\text {nss }}\right)$ was calculated using the mass ratio of $\left(\mathrm{ssSO}_{4}^{2-} / \mathrm{Na}^{+}\right)=0.252 \mathrm{~g} / \mathrm{g}$ in seawater (Millero et al., 2008). For the Malaspina samples, due to a sodium blank in the quartz fiber filters, we calculated $f_{\text {nss }}$ using the mass ratio of $\left(\mathrm{ssSO}_{4}^{2-} / \mathrm{Mg}^{2+}\right)=2.115 \mathrm{~g} / \mathrm{g}$ in seawater (Millero et al., 2008). Only samples with $f_{\text {nss }}$ larger than $30 \%$ were used in this study, to minimize the effect of uncertainty in the $\mathrm{ssSO}_{4}^{2-}$ fraction on calculations of $\Delta^{17} \mathrm{O}\left(\mathrm{nssSO}_{4}^{2-}\right)$. In the end, 25 Malaspina and $42 \mathrm{Xue}$ Long samples were used in this study, for a total of 67 (out of 91) samples. The averaged $f_{\mathrm{nss}}$ is $0.57 \pm 0.21$ and $0.74 \pm 0.19(1 \sigma)$ for the 25 Malaspina and 42 Xue Long samples, respectively.
The samples are divided into four categories (Fig. 2): (I) Southern Ocean, (II) Antarctic coast, (III) subtropical MBL and (IV) tropical coasts, based on their geographical location. The number of samples is 13, 18, 19 and 17 for Categories I, II, III and IV, respectively.

$\Delta^{17} \mathrm{O}$ of sulfate on the aerosol filter samples were measured using the pyrolysis method described in detail in Geng et al. (2013). Briefly, the sulfate on the filters was first dissolved in $18 \mathrm{M} \Omega$ water, purified using ion chromatography, and converted to $\mathrm{Na}_{2} \mathrm{SO}_{4}$ using ion exchange resin (AG 50 W-X8, 100-200 mesh, $\mathrm{H}^{+}$form, Bio-Rad, Hercules, CA, USA); $30 \% \mathrm{H}_{2} \mathrm{O}_{2}$ solution was added to remove organics, and $\mathrm{Na}_{2} \mathrm{SO}_{4}$ was then converted to $\mathrm{Ag}_{2} \mathrm{SO}_{4}$ using the ion exchange resin. The $\mathrm{Ag}_{2} \mathrm{SO}_{4}$ was dried to a solid in a quartz cup and each sample was placed in a zero-blank autosampler attached to the continuous-flow inlet of the isotope ratio mass spectrometer (IRMS). Each $\mathrm{Ag}_{2} \mathrm{SO}_{4}$ sample was individually dropped into a furnace $\left(1000^{\circ} \mathrm{C}\right)$ under a continuous flow of helium (He) where it is pyrolyzed to form $\mathrm{Ag}(\mathrm{s})+\mathrm{SO}_{2}(\mathrm{~g})+\mathrm{O}_{2}(\mathrm{~g})$. The byproduct $\mathrm{Ag}(\mathrm{s})$ condenses on the walls of the quartz pyrolysis tube, while the byproduct $\mathrm{SO}_{2}(\mathrm{~g})$ was removed from the He flow with a cryogenic trap at liquid nitrogen temperature $(\approx 77 \mathrm{~K})$. The remaining product $\mathrm{O}_{2}(\mathrm{~g})$ is carried along the He flow to the IRMS, where the abundance of ${ }^{16} \mathrm{O},{ }^{17} \mathrm{O}$, and ${ }^{18} \mathrm{O}$ in $\mathrm{O}_{2}$ was measured, and from which $\Delta^{17} \mathrm{O}$ was calculated. Fifty-four samples were measured in triplicate, nine samples were measured in duplicate, and four samples were measured once. The precision of $\Delta^{17} \mathrm{O}$ is typically better than $\pm 0.3 \%$ o based on replicate analysis of standards. The $\Delta^{17} \mathrm{O}$ obtained from IRMS is the $\Delta^{17} \mathrm{O}$ of total sulfate on the aerosol samples $\left(\Delta^{17} \mathrm{O}\left(\mathrm{SO}_{4}^{2-}\right)\right)$. $\Delta^{17} \mathrm{O}\left(\mathrm{nssSO}_{4}^{2-}\right)$ was calculated by dividing $\Delta^{17} \mathrm{O}\left(\mathrm{SO}_{4}^{2-}\right)$ by $f_{\text {nss }}$, as $\Delta^{17} \mathrm{O}\left(\mathrm{ssSO}_{4}^{2-}\right)=0 \%$ o (Bao et al., 2000). 


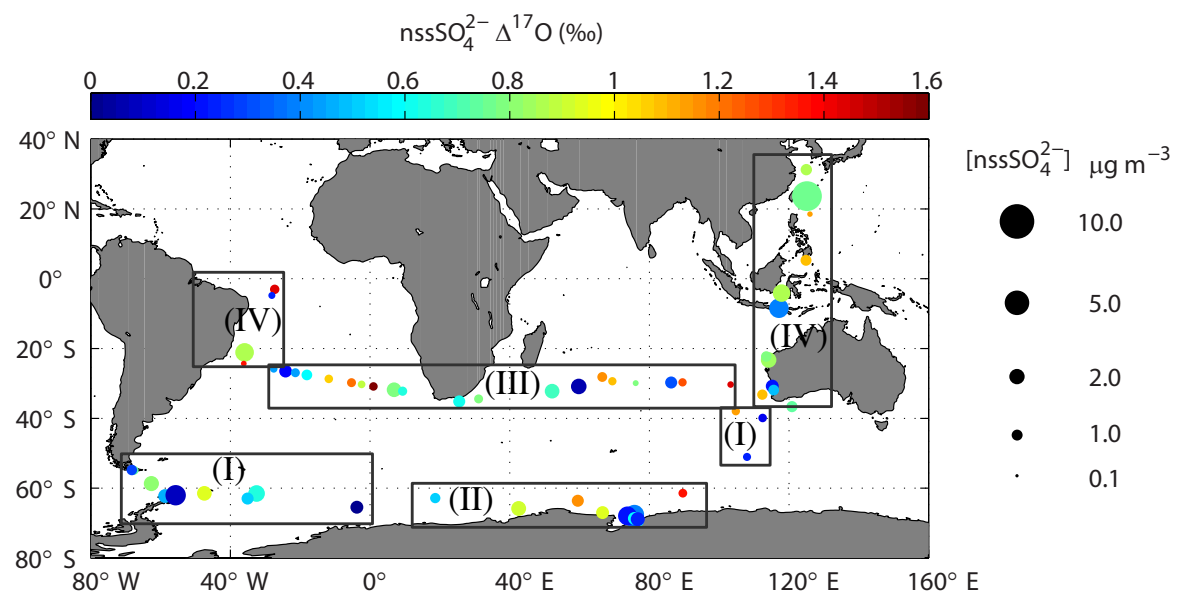

Figure 2. Observations of $\Delta^{17} \mathrm{O}\left(\mathrm{nssSO}_{4}^{2-}\right)\left(\%\right.$ ) and $\mathrm{nssSO}_{4}^{2-}$ concentration $\left(\mu \mathrm{g} \mathrm{m}^{-3}\right)$ for aerosol samples collected in the $\mathrm{MBL}$ during spring and summer in 2011 and 2012. Black rectangles indicate regions I-IV.

\section{GEOS-Chem model}

We use v9-02 of the GEOS-Chem global three-dimensional model (http://www.geos-chem.org/) of coupled oxidantaerosol chemistry (Park et al., 2004) to simulate atmospheric sulfur chemistry and interpret our $\Delta^{17} \mathrm{O}\left(\mathrm{nssSO}_{4}^{2-}\right)$ observations. The model is driven by assimilated meteorological data from the NASA Goddard Earth Observing System (GEOS5, http://gmao.gsfc.nasa.gov), which has a temporal resolution of $6 \mathrm{~h}$, with $3 \mathrm{~h}$ for surface quantities and mixing depths. Model simulations for the analysis of the cruise data were performed at $2^{\circ} \times 2.5^{\circ}$ horizontal resolution and 47 vertical levels up to $0.01 \mathrm{hPa}$ using GEOS-5 meteorology corresponding to the timing of sample collection, after spinning up the model for 1 year.

The sulfate simulations were conducted in aerosol-only mode that used archived monthly mean $\mathrm{OH}, \mathrm{NO}_{3}, \mathrm{O}_{3}$ and total nitrate concentrations and production and loss rates for $\mathrm{H}_{2} \mathrm{O}_{2}$ from the full-chemistry simulation as described in Park et al. (2004). A diurnal variation as a function of solar zenith angle is applied to $\mathrm{OH}$ concentrations and photolytic loss rates of $\mathrm{H}_{2} \mathrm{O}_{2}$ in the model. $\mathrm{NO}_{3}$ is set to be zero during daytime. Sulfate in the model was produced from gasphase oxidation of $\mathrm{SO}_{2}(\mathrm{~g})$ by $\mathrm{OH}$, aqueous-phase oxidation of $\mathrm{S}(\mathrm{IV})$ by $\mathrm{H}_{2} \mathrm{O}_{2}, \mathrm{O}_{3}$, and metal-catalyzed $\mathrm{O}_{2}$ (Alexander et al., 2009), and heterogeneous oxidation on sea-salt aerosols by $\mathrm{O}_{3}$ (Alexander et al., 2005). The parameterization of the metal-catalyzed S(IV) oxidation pathway is described in detail in Alexander et al. (2009). The trace metals included are $\mathrm{Fe}$ and $\mathrm{Mn}$, whose oxidation states $\mathrm{Fe}(\mathrm{III})$ and $\mathrm{Mn}$ (II) catalyze $\mathrm{S}(\mathrm{IV})$ oxidation. Soil-derived $\mathrm{Fe}\left([\mathrm{Fe}]_{\text {soil }}\right)$ is scaled to modeled dust concentration as $3.5 \%$ of total dust mass, while soil-derived $\mathrm{Mn}\left([\mathrm{Mn}]_{\text {soil }}\right)$ is a factor of 50 lower than $[\mathrm{Fe}]_{\text {soil }}$. Anthropogenic $\mathrm{Mn}\left([\mathrm{Mn}]_{\text {anthro }}\right)$ is scaled as $1 / 300$ of primary sulfate concentration, while anthropogenic $\mathrm{Fe}$
$\left([\mathrm{Fe}]_{\mathrm{anthro}}\right)$ is 10 times that of $[\mathrm{Mn}]_{\mathrm{anthro}}$. We assume that $50 \%$ of $\mathrm{Mn}$ is dissolved in cloud water as $\mathrm{Mn}$ (II) oxidation state. For $\mathrm{Fe}$, we assume that $10 \%$ of $[\mathrm{Fe}]_{\text {anthro }}$ and $1 \%$ of $[\mathrm{Fe}]_{\text {soil }}$ is dissolved in cloud water; $10 \%$ of the dissolved $\mathrm{Fe}$ is in $\mathrm{Fe}(\mathrm{III})$ oxidation state during daytime and $90 \%$ at night. Primary anthropogenic emissions of sulfate are $3.5 \%$ of total anthropogenic sulfur emissions in Europe, an average of $1.5 \%$ in North America and $2.1 \%$ elsewhere. The anthropogenic emission inventories used in this study are global emission inventory EDGAR v3 (Olivier et al., 2001) supplemented by regional inventories such as STREETS (Streets et al., 2006), EMEP (Vestreng and Klein, 2002), and NEI2005 (Van Donkelaar et al., 2012). The oceanic DMS inventory is from Kettle et al. (1999). Sulfate formed from each oxidation pathway was treated as a separate "tracer" in the model with a corresponding $\Delta \Delta^{17} \mathrm{O}$ value as shown in Table 1. Primary anthropogenic sulfate has a $\Delta^{17} \mathrm{O}$ of $0 \%$ (Lee et al., 2002). The model calculates $\Delta^{17} \mathrm{O}$ of bulk sulfate in the grid box $\left(\Delta^{17} \mathrm{O}_{\text {mod }}\left(\mathrm{nssSO}_{4}^{2-}\right)\right)$ based on the relative importance of each sulfate production mechanism for total sulfate abundance. This is then compared to the $\Delta^{17} \mathrm{O}$ measurement of bulk sulfate collected on aerosol filters $\left(\Delta^{17} \mathrm{O}_{\mathrm{obs}}\left(\mathrm{nssSO}_{4}^{2-}\right)\right)$ to investigate sulfate formation mechanisms in the MBL (Sect. 4.2).

For pH-dependent S(IV) partitioning, bulk cloud water $\mathrm{pH}$ is calculated as described in Alexander et al. (2012). Large-scale models such as GEOS-Chem calculate the average chemistry of bulk cloud water rather than the chemistry of individual cloud droplets. This approach has been shown to significantly underestimate sulfate formation via oxidation of $\mathrm{SO}_{3}^{2-}$ by $\mathrm{O}_{3}$ by underestimating the fraction of $\mathrm{S}(\mathrm{IV})$ present as $\mathrm{SO}_{3}^{2-}$ (Hegg et al., 1992; O'Dowd et al., 2000; Roelofs, 1993; Yuen et al., 1996; Fahey and Pandis, 2003). We use the Fahey and Pandis (2003) algorithm and the Yuen et al. (1996) parameterization in GEOS-Chem to account for 
the effect of heterogeneity in cloud drop $\mathrm{pH}$ on S(IV) partitioning as described in Alexander et al. (2012).

\section{Results}

\subsection{Observations of $\Delta^{17} \mathrm{O}\left(\mathrm{nsSSO}_{4}^{2-}\right)$ and $\mathrm{nsSSO}_{4}^{2-}$ concentrations}

Except for one sample near the coast of China with a relatively high concentration of $\mathrm{nssSO}_{4}^{2-}\left(\left[\mathrm{SO}_{4}^{2-}\right]_{\mathrm{nss}}\right)$ $\left(7.4 \mu \mathrm{g} \mathrm{m}^{-3}\right)$, the $\left[\mathrm{SO}_{4}^{2-}\right]_{\mathrm{nss}}$ observations vary from 0.2 to $3.5 \mu \mathrm{g} \mathrm{m}^{-3}$, with an average of $1.2 \pm 0.8(1 \sigma) \mu \mathrm{g} \mathrm{m}^{-3}$. Averaged $\left[\mathrm{SO}_{4}^{2-}\right]_{\mathrm{nss}}$ is $1.4 \pm 0.8,1.4 \pm 0.7,0.9 \pm 0.5$ and $1.3 \pm 0.9(1 \sigma) \mu \mathrm{g} \mathrm{m}^{-3}$ for samples in Categories I, II, III and $\mathrm{IV}$, respectively (Table 2). A latitudinal gradient of $\left[\mathrm{SO}_{4}^{2-}\right]_{\mathrm{nss}}$ is found in our data, where averaged $\left[\mathrm{SO}_{4}^{2-}\right]_{\mathrm{nss}}$ between 50 and $70^{\circ} \mathrm{S}$ is $50 \%$ higher than samples between 20 and $40^{\circ} \mathrm{S}$ $\left(1.5 \mathrm{vs} .1 .0 \mu \mathrm{g} \mathrm{m}^{-3}\right)$. The difference is significant at the $95 \%$ confidence level.

Figure 2 shows the observations of $\Delta^{17} \mathrm{O}\left(\mathrm{nssSO}_{4}^{2-}\right)$ $\left(\Delta^{17} \mathrm{O}_{\text {obs }}\left(\mathrm{nssSO}_{4}^{2-}\right)\right)$ and $\mathrm{nssSO}_{4}^{2-}$ concentration $\left(\left[\mathrm{SO}_{4}^{2-}\right]_{\mathrm{nss}}\right)$ at each sampling location. $\Delta^{17} \mathrm{O}_{\mathrm{obs}}\left(\mathrm{nssSO}_{4}^{2-}\right)$ values range from 0.0 to $1.6 \%$, with an average of $0.7 \pm 0.4$ $(1 \sigma) \%$ o. Averaged $\Delta^{17} \mathrm{O}_{\text {obs }}\left(\mathrm{nssSO}_{4}^{2-}\right)$ (Table 2) is $0.5 \pm 0.3$, $0.7 \pm 0.4,0.8 \pm 0.4$ and $0.8 \pm 0.4(1 \sigma) \%$ for samples in Categories I, II, III and IV, respectively. The analytical error in $\Delta^{17} \mathrm{O}_{\text {obs }}\left(\mathrm{nssSO}_{4}^{2-}\right)$ is estimated by calculating the standard deviation $(1 \sigma)$ of the multiple measurements of each sample, which range from \pm 0.0 to $0.4 \%$ with an average of $\pm 0.1 \%$. Though $\Delta^{17} \mathrm{O}_{\text {obs }}\left(\mathrm{nssSO}_{4}^{2-}\right)$ in Category I (over the Southern Ocean) is slightly lower than those in other categories, the $<0.3 \%$ difference between each category is generally smaller than the measurement uncertainty estimated from replicate analysis of standards.

Only sulfate formed via $\mathrm{H}_{2} \mathrm{O}_{2}$ and $\mathrm{O}_{3}$ oxidation has a positive $\Delta^{17} \mathrm{O}\left(\mathrm{nssSO}_{4}^{2-}\right)$, with $\mathrm{H}_{2} \mathrm{O}_{2}$ oxidation leading to $\Delta^{17} \mathrm{O}\left(\mathrm{nssSO}_{4}^{2-}\right)=0.7 \%$ and $\mathrm{O}_{3}$ oxidation leading to $\Delta^{17} \mathrm{O}\left(\mathrm{nssSO}_{4}^{2-}\right)=6.5 \%$. We can calculate the maximum contribution from " $\mathrm{S}(\mathrm{IV})+\mathrm{O}_{3}$ " $\left(f_{\mathrm{O}_{3}, \max }\right)$ for each sulfate sample by assuming no contribution from $\mathrm{H}_{2} \mathrm{O}_{2}$ (i.e., all of the aqueous-phase $\mathrm{S}(\mathrm{IV})$ oxidation occurs via $\mathrm{O}_{3}$ oxidation):

$f_{\mathrm{O}_{3}, \max }=\frac{\Delta^{17} \mathrm{O}_{\mathrm{obs}}\left(\mathrm{nssSO}_{4}^{2-}\right)}{\Delta^{17} \mathrm{O}\left(\mathrm{nssSO}_{4}^{2-}\right)_{\mathrm{O}_{3}}}$,

where $\Delta^{17} \mathrm{O}\left(\mathrm{nssSO}_{4}^{2-}\right) \mathrm{O}_{3}=6.5 \%$. This yields $f_{\mathrm{O}_{3} \text {, max }}$ ranging from 0.00 to 0.26 with an average of $0.12 \pm 0.06(1 \sigma)$ for all samples. Averaged $f_{\mathrm{O}_{3}, \max }$ is $0.08 \pm 0.05,0.11 \pm 0.06,0.13 \pm 0.07$ and $0.13 \pm 0.06(1 \sigma)$ for samples in Categories I, II, III and IV, respectively (Table 2). For samples with $\Delta^{17} \mathrm{O}_{\text {obs }}\left(\mathrm{nssSO}_{4}^{2-}\right.$ ) larger than $0.7 \%$ ( 36 samples), we can calculate the minimum $\mathrm{O}_{3}$ contribution $\left(f_{\mathrm{O}_{3}}, \mathrm{~min}\right)$ by assuming that $\mathrm{H}_{2} \mathrm{O}_{2}$ is the only

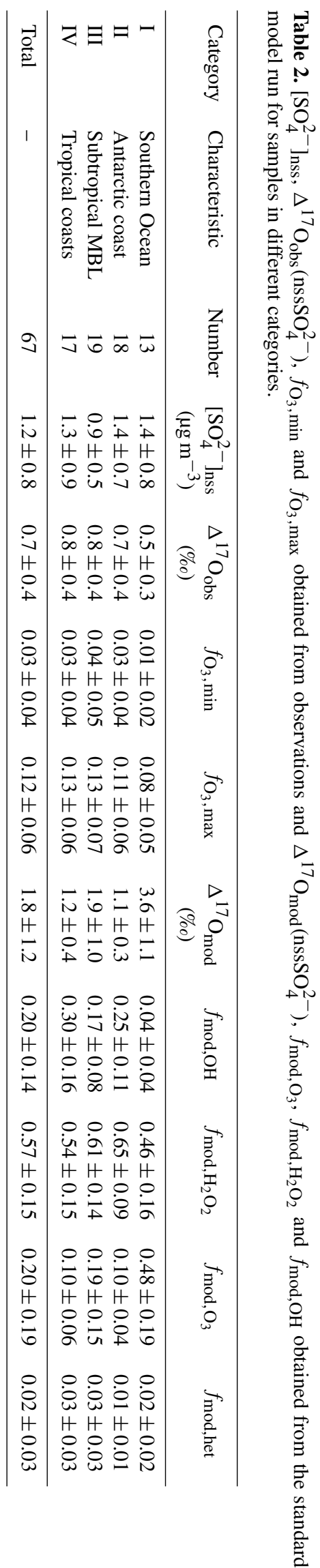

www.atmos-chem-phys.net/16/11433/2016/ 


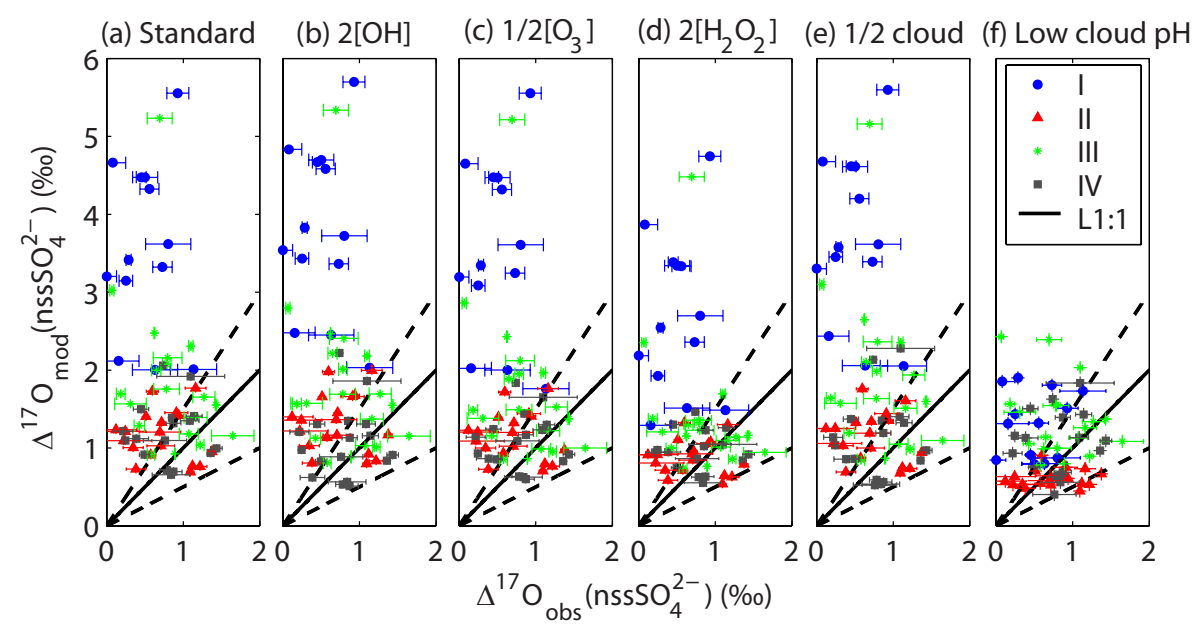

Figure 3. $\Delta^{17} \mathrm{O}_{\text {mod }}\left(\mathrm{nssSO}_{4}^{2-}\right)$ vs. $\Delta^{17} \mathrm{O}_{\mathrm{obs}}\left(\mathrm{nssSO}_{4}^{2-}\right)$ for different model simulations: (a) standard run, (b) double OH concentration, (c) half $\mathrm{O}_{3}$ concentration, (d) double $\mathrm{H}_{2} \mathrm{O}_{2}$ concentration, (e) half clouds and (f) low cloud $\mathrm{pH}$.

other oxidation pathway (i.e., no significant contribution from $\mathrm{OH}$ and HOX oxidation):

$f_{\mathrm{O}_{3}, \min }=\frac{\Delta^{17} \mathrm{O}_{\mathrm{obs}}\left(\mathrm{nssSO}_{4}^{2-}\right)-\Delta^{17} \mathrm{O}\left(\mathrm{nssSO}_{4}^{2-}\right)_{\mathrm{H}_{2} \mathrm{O}_{2}}}{\Delta^{17} \mathrm{O}\left(\mathrm{nssSO}_{4}^{2-}\right)_{\mathrm{O}_{3}}-\Delta^{17} \mathrm{O}\left(\mathrm{nssSO}_{4}^{2-}\right)_{\mathrm{H}_{2} \mathrm{O}_{2}}}$,

where $\Delta^{17} \mathrm{O}\left(\mathrm{nssSO}_{4}^{2-}\right) \mathrm{H}_{2} \mathrm{O}_{2}=0.7 \%$. For samples with $\Delta \Delta^{17} \mathrm{O}_{\mathrm{obs}}\left(\mathrm{nssSO}_{4}^{2-}\right.$ ) smaller than $0.7 \%$ (31 samples), $f_{\mathrm{O}_{3}, \min }$ is 0 . We obtain $f_{\mathrm{O}_{3}}$,min ranging from 0.00 to 0.16 with an average of $0.03 \pm 0.04(1 \sigma)$ among all samples. Averaged $f_{\mathrm{O}_{3}}$, min is $0.01 \pm 0.02,0.03 \pm 0.04,0.04 \pm 0.05$ and $0.03 \pm 0.04(1 \sigma)$ for samples in Categories I, II, III and IV, respectively (Table 2 ).

\subsection{Comparison of modeled vs. observed $\Delta^{17} \mathrm{O}\left(\mathrm{nsSSO}_{4}^{2-}\right)$}

Figure 3a shows the comparison between modeled and observed $\quad \Delta^{17} \mathrm{O}\left(\mathrm{nssSO}_{4}^{2-}\right) \quad\left(\Delta^{17} \mathrm{O}_{\bmod }\left(\mathrm{nssSO}_{4}^{2-}\right) \quad\right.$ vs. $\Delta^{17} \mathrm{O}_{\text {obs }}\left(\mathrm{nssSO}_{4}^{2-}\right)$ ) for the standard model run (as described in Sect. 3). $\Delta^{17} \mathrm{O}_{\bmod }\left(\mathrm{nssSO}_{4}^{2-}\right)$ represents the daily mean in the first vertical model level (below $\approx 100 \mathrm{~m}$ ) at each of our sampling locations. The range of $\Delta^{17} \mathrm{O}_{\text {mod }}\left(\mathrm{nssSO}_{4}^{2-}\right)$ is $0.7-5.6 \%$, overestimating the observations on average by a factor of 2.5. Averaged $\Delta^{17} \mathrm{O}_{\bmod }\left(\mathrm{nssSO}_{4}^{2-}\right)$ is $3.6 \pm 1.1$, $1.1 \pm 0.3,1.9 \pm 1.0$ and $1.2 \pm 0.4(1 \sigma) \%$ o for samples in Categories I, II, III and IV, respectively. $\Delta^{17} \mathrm{O}_{\text {mod }}\left(\mathrm{nssSO}_{4}^{2-}\right)$ overestimates $\Delta^{17} \mathrm{O}_{\mathrm{obs}}\left(\mathrm{nssSO}_{4}^{2-}\right)$ in all categories (Table 2). The discrepancy between $\Delta^{17} \mathrm{O}_{\bmod }\left(\mathrm{nsSSO}_{4}^{2-}\right)$ and $\Delta^{17} \mathrm{O}_{\text {obs }}\left(\mathrm{nssSO}_{4}^{2-}\right)$ is most evident for samples in Category I (Southern Ocean), for which the model predicts that $48 \%$ of sulfate will be formed via $\mathrm{O}_{3}$ pathways, compared to $1-8 \%$ estimated from the observations alone.
The model calculated fractional contributions to the sulfate burden from each oxidant, averaged over all samples, are $f_{\text {mod, } \mathrm{OH}}=0.20 \pm 0.14(1 \sigma), \quad f_{\text {mod, } \mathrm{H}_{2} \mathrm{O}_{2}}=0.57 \pm 0.15(1 \sigma)$, $f_{\text {mod, } \mathrm{O}_{3}}=0.20 \pm 0.19(1 \sigma)$ and $f_{\text {mod,het }}=0.02 \pm 0.03(1 \sigma)$, where $f_{\text {mod, } \mathrm{OH}}, f_{\text {mod, } \mathrm{H}_{2} \mathrm{O}_{2}}, f_{\text {mod, } \mathrm{O}_{3}}$ and $f_{\text {mod,het }}$ represent the fractional contribution of gas-phase $\mathrm{OH}$ oxidation, in-cloud $\mathrm{H}_{2} \mathrm{O}_{2}$ oxidation, in-cloud $\mathrm{O}_{3}$ oxidation and heterogeneous oxidation by $\mathrm{O}_{3}$ on the surface of sea-salt aerosol to the total sulfate burden, respectively. The corresponding fractional contributions for samples in different categories are shown in Table 2. $f_{\mathrm{mod}, \mathrm{O}_{3}}$ is largest in Category I (0.48) and smallest in Categories II and IV (0.10), while $f_{\text {mod,OH }}$ is largest in Category IV (0.30) and smallest in Category I (0.04). Sulfate formation from in-cloud metal-catalyzed oxidation by $\mathrm{O}_{2}$ and direct emission of anthropogenic sulfate contribute less than $1 \%$ of total sulfate in our samples and thus will be neglected in the discussion below.

Based on the modeled fractional contributions to the sulfate burden from each oxidant except HOX, and knowledge about reaction rate constants of "HOX $+\mathrm{S}(\mathrm{IV})$ " reactions and Henry's law constants of HOX, we calculate the amount of HOX needed to explain the discrepancy between $\Delta^{17} \mathrm{O}_{\text {mod }}\left(\mathrm{nssSO}_{4}^{2-}\right)$ and $\Delta^{17} \mathrm{O}_{\text {obs }}\left(\mathrm{nssSO}_{4}^{2-}\right)$ in Sect. 5.2.4.

\section{Discussion}

\subsection{Observations of $\Delta^{17} \mathrm{O}\left(\mathrm{nssSO}_{4}^{2-}\right)$ and $\mathrm{nsSSO}_{4}^{2-}$ concentrations}

Our observations of $\mathrm{nssSO}_{4}^{2-}$ concentrations (0.2$\left.3.5 \mu \mathrm{g} \mathrm{m}^{-3}\right)$ are consistent with those $\left(<2 \mu \mathrm{g} \mathrm{m}^{-3}\right)$ over the Southern Ocean measured by Sievering et al. (2004). Other published data for samples with air originating from the remote Atlantic Ocean showed a $\left[\mathrm{SO}_{4}^{2-}\right]_{\text {nss }}$ between 0.9 
and $4.5 \mu \mathrm{g} \mathrm{m}^{-3}$ (Alexander et al., 2012), consistent with our observations. Higher observed $\left[\mathrm{SO}_{4}^{2-}\right]_{\text {nss }}$ between 50 and $70^{\circ} \mathrm{S}$ compared to $20-40^{\circ} \mathrm{S}$ could be due to a higher DMS emission flux over $50-70^{\circ} \mathrm{S}$ (Boucher et al., 2003).

Previous studies have suggested a large contribution to sulfate formation from $\mathrm{O}_{3}$ oxidation in the MBL as the aqueousphase reaction between $\mathrm{S}(\mathrm{IV})$ and $\mathrm{O}_{3}$ is very fast at $\mathrm{pH}>5$ (Chameides and Stelson, 1992; Sievering et al, 1991, 2004; O'Dowd et al., 2000; Alexander et al., 2012). These studies did not consider the HOX mechanism due to the large uncertainty in the reaction rates. As the reaction of HOX with $\mathrm{SO}_{3}^{2-}$ is also fast $\left(k_{\mathrm{HOBr}}+\mathrm{SO}_{3}^{2-}=5 \times 10^{9} \mathrm{M}^{-1} \mathrm{~s}^{-1}\right.$ and $\left.k_{\mathrm{HOCl}+\mathrm{SO}_{3}^{2-}}=7.6 \times 10^{8} \mathrm{M}^{-1} \mathrm{~s}^{-1}\right)$, cloud $\mathrm{pH}>5$ will promote rapid aqueous-phase sulfate formation by HOX in addition to $\mathrm{O}_{3}$. A large contribution from $\mathrm{O}_{3}$ will yield a high $\Delta^{17} \mathrm{O}\left(\mathrm{nssSO}_{4}^{2-}\right)$ value $(6.5 \%)$, but most samples in this study have low $\Delta^{17} \mathrm{O}\left(\mathrm{nssSO}_{4}^{2-}\right)$ values $(0.7 \pm 0.4 \%$ o). Thus, our results argue against a significant role of sulfate formation via $\mathrm{O}_{3}$ oxidation in remote MBL. Indeed, our calculated $\mathrm{O}_{3}$ contribution range $\left(f_{\mathrm{O}_{3}, \min }=0.03, f_{\mathrm{O}_{3}, \max }=0.12\right)$ is more consistent with that reported by von Glasow et al. (2002), who did consider HOX. Their simulations of sulfate production in the MBL yielded a calculated $\mathrm{O}_{3}$ contribution of $2-8 \%$ to the total sulfate production, while HOX contributed about $30 \%$.

In comparison, Alexander et al. (2012) showed observations of $\Delta^{17} \mathrm{O}\left(\mathrm{nssSO}_{4}^{2-}\right)$ of $1.1-1.4 \%$ o for samples with back trajectories over the Iberian Peninsula during summer and $2.2-7.3 \%$ or samples with back trajectories over the Atlantic Ocean during winter. Their results suggested sulfate formation via HOX oxidation is not significant over subtropical northeast Atlantic during winter but potentially important in the more polluted coastal location of the Iberian Peninsula during summer. Our samples show lower $\Delta^{17} \mathrm{O}\left(\mathrm{nssSO}_{4}^{2-}\right)$ than Alexander et al. (2012) in general, but were collected at different locations and during different seasons.

\subsection{Comparison of modeled vs. observed $\Delta^{17} \mathbf{O}\left(\mathrm{nssSO}_{4}^{2-}\right)$}

As shown in Fig. 3a, the standard model significantly overestimates observations of $\Delta^{17} \mathrm{O}\left(\mathrm{nssSO}_{4}^{2-}\right)$. This could be caused by the model (1) overestimating $\left(\mathrm{O}_{3}\right)$ or underestimating $\left(\mathrm{OH}, \mathrm{H}_{2} \mathrm{O}_{2}\right)$ oxidant abundances, (2) overestimating the amount of clouds, (3) overestimating the $\mathrm{pH}$ of clouds, or (4) neglecting sulfate formation from HOX oxidation. In this section, we examine each of these possibilities.

\subsubsection{Oxidant sensitivity simulations}

To investigate the impact of model biases in oxidant concentrations on calculated $\Delta^{17} \mathrm{O}\left(\mathrm{nssSO}_{4}^{2-}\right)$, we perform three sensitivity runs by (1) doubling $\mathrm{OH}$ concentrations, (2) halving $\mathrm{O}_{3}$ concentrations and (3) doubling $\mathrm{H}_{2} \mathrm{O}_{2}$ concentrations everywhere in the model. Fig- ure $3 \mathrm{~b}-\mathrm{d}$ show $\Delta^{17} \mathrm{O}_{\text {mod }}\left(\mathrm{nssSO}_{4}^{2-}\right)$ vs. $\Delta^{17} \mathrm{O}_{\text {obs }}\left(\mathrm{nssSO}_{4}^{2-}\right)$ for these three sensitivity runs. The discrepancy between $\Delta^{17} \mathrm{O}_{\text {mod }}\left(\mathrm{nssSO}_{4}^{2-}\right)$ and $\Delta^{17} \mathrm{O}_{\text {obs }}\left(\mathrm{nssSO}_{4}^{2-}\right)$ is not reconciled by changing the oxidant concentrations in the model. On average, $\Delta^{17} \mathrm{O}_{\text {mod }}\left(\mathrm{nssSO}_{4}^{2-}\right)$ changes to $1.9 \pm 1.3$, $1.8 \pm 1.2$ and $1.4 \pm 0.9 \%$ o for doubling $\mathrm{OH}$ concentrations, halving $\mathrm{O}_{3}$ concentrations and doubling $\mathrm{H}_{2} \mathrm{O}_{2}$ concentrations, respectively, compared to $1.8 \pm 1.2 \%$ for the standard run.

Doubling modeled $\mathrm{OH}$ concentrations results in an increase in the mass fraction of sulfate formed via gas-phase oxidation by $\mathrm{OH}\left(f_{\mathrm{mod}, \mathrm{OH}}\right)$ from 0.20 to 0.27 and a decrease via aqueous-phase oxidation by $\mathrm{H}_{2} \mathrm{O}_{2}$ and $\mathrm{O}_{3}\left(f_{\text {mod,aq }}=\right.$ $f_{\text {mod, } \mathrm{H}_{2} \mathrm{O}_{2}}+f_{\text {mod, } \mathrm{O}_{3}}$ ) from 0.77 to 0.70 (Table $3 \mathrm{a}$ ). This would be expected to result in lower $\Delta^{17} \mathrm{O}_{\bmod }\left(\mathrm{nssSO}_{4}^{2-}\right)$ as long as the relative importance of $\mathrm{H}_{2} \mathrm{O}_{2}$ and $\mathrm{O}_{3}$ in the aqueous phase remains constant. However, doubling $\mathrm{OH}$ results in a small increase in $f_{\text {mod, } \mathrm{O}_{3}}$ from 0.20 to 0.22 (Table 3a). The small increase in $f_{\text {mod, } \mathrm{O}_{3}}$ occurs because of the reduction in the aqueous-phase sulfate production rate, which is caused by lower $\mathrm{S}(\mathrm{IV})$ due to faster removal of $\mathrm{SO}_{2}$ by $\mathrm{OH}$ in the gas phase. A reduction in the aqueous-phase sulfate formation rate results in higher cloud-water $\mathrm{pH}$, which increases the fraction of sulfate produced from $\mathrm{O}_{3}$ oxidation, even though the total aqueous-phase sulfate production decreases. Thus, doubling $\mathrm{OH}$ concentrations has an insignificant effect on $\Delta^{17} \mathrm{O}_{\text {mod }}\left(\mathrm{nssSO}_{4}^{2-}\right)$. The nighttime $\mathrm{OH}$ concentrations observed in forests and urban areas (Faloona et al., 2001; Lu et al., 2014) should also have insignificant effects on our model results as most of our samples are collected in the remote MBL where isoprene and VOCs abundances are low. Our sensitivity study with doubled $\mathrm{OH}$ suggests additional nighttime sources of $\mathrm{OH}$ would not resolve the modeled overestimate of $\Delta^{17} \mathrm{O}\left(\mathrm{nssSO}_{4}^{2-}\right)$ observations.

Halving modeled $\mathrm{O}_{3}$ concentrations results in a small decrease in $f_{\text {mod, } \mathrm{O}_{3}}$ from 0.20 to 0.19 and a change of less than 0.01 in $f_{\text {mod,aq }}$ (Table $3 \mathrm{~b}$ ). The decrease in $f_{\text {mod, } \mathrm{O}_{3}}$ is small because $f_{\text {mod, } \mathrm{O}_{3}}$ is mainly regulated by the cloud $\mathrm{pH}$ rather than $\mathrm{O}_{3}$ abundance. In other words, the sulfate burden from $\mathrm{O}_{3}$ oxidation is limited by concentration of $\mathrm{SO}_{3}^{2-}$, not $\mathrm{O}_{3}$. As a result, halving $\mathrm{O}_{3}$ has an insignificant effect on $\Delta^{17} \mathrm{O}_{\bmod }\left(\mathrm{nssSO}_{4}^{2-}\right)$.

Doubling modeled $\mathrm{H}_{2} \mathrm{O}_{2}$ concentrations results in an increase in $f_{\text {mod, } \mathrm{H}_{2} \mathrm{O}_{2}}$ from 0.57 to 0.66 , a decrease in $f_{\text {mod, } \mathrm{O}_{3}}$ from 0.20 to 0.14 (Table $3 \mathrm{c}$ ) and an increase in $f_{\text {mod,aq }}$ from 0.77 to 0.80 . The increase in $f_{\text {mod, } \mathrm{H}_{2} \mathrm{O}_{2}}$ causes an increase in $\Delta^{17} \mathrm{O}_{\text {mod }}\left(\mathrm{nssSO}_{4}^{2-}\right)$ of less than $0.1 \%$, which is a small effect compared to the change in $f_{\text {mod, } \mathrm{O}_{3}}$ that results in a decrease in $\Delta^{17} \mathrm{O}_{\text {mod }}\left(\mathrm{nssSO}_{4}^{2-}\right)$ of $0.4 \%$. The decrease in $f_{\text {mod, } \mathrm{O}_{3}}$ is caused by the decrease in cloud $\mathrm{pH}$ due to a higher aqueous-phase sulfate production rate. Although doubling $\mathrm{H}_{2} \mathrm{O}_{2}$ results in a decrease in $\Delta{ }^{17} \mathrm{O}_{\text {mod }}\left(\mathrm{nssSO}_{4}^{2-}\right)$ of $0.4 \%$ o on average, it is still too small to reconcile the $1.1 \%$ o discrepancy between $\Delta^{17} \mathrm{O}_{\text {mod }}\left(\mathrm{nssSO}_{4}^{2-}\right)$ and $\Delta^{17} \mathrm{O}_{\mathrm{obs}}\left(\mathrm{nssSO}_{4}^{2-}\right)$. 
Table 3. $\Delta^{17} \mathrm{O}_{\text {mod }}\left(\right.$ nssSO $\left._{4}^{2-}\right), f_{\text {mod, } \mathrm{O}_{3}}, f_{\text {mod, } \mathrm{H}_{2} \mathrm{O}_{2}}$ and $f_{\text {mod,OH }}$ obtained from five sensitivity studies: (a) double OH concentration, (b) half $\mathrm{O}_{3}$ concentration, (c) double $\mathrm{H}_{2} \mathrm{O}_{2}$ concentration, (d) half clouds and (e) low cloud $\mathrm{pH}$.

\begin{tabular}{lccccc}
\hline Category & $\begin{array}{c}\Delta^{17} \mathrm{O}_{\text {mod }} \\
(\% \circ)\end{array}$ & $f_{\text {mod, } \mathrm{OH}}$ & $f_{\text {mod, } \mathrm{H}_{2} \mathrm{O}_{2}}$ & $f_{\text {mod, }} 3$ & $f_{\text {mod,het }}$ \\
\hline (a) $2[\mathrm{OH}]$ & & & & & \\
\hline I & $3.8 \pm 1.1$ & $0.06 \pm 0.05$ & $0.39 \pm 0.14$ & $0.53 \pm 0.18$ & $0.02 \pm 0.02$ \\
II & $1.3 \pm 0.4$ & $0.29 \pm 0.11$ & $0.57 \pm 0.09$ & $0.13 \pm 0.05$ & $0.01 \pm 0.01$ \\
III & $1.8 \pm 1.0$ & $0.25 \pm 0.11$ & $0.51 \pm 0.13$ & $0.20 \pm 0.16$ & $0.03 \pm 0.03$ \\
IV & $1.1 \pm 0.5$ & $0.42 \pm 0.19$ & $0.43 \pm 0.17$ & $0.09 \pm 0.06$ & $0.02 \pm 0.03$ \\
\hline Total & $1.9 \pm 1.3$ & $0.27 \pm 0.17$ & $0.48 \pm 0.15$ & $0.22 \pm 0.20$ & $0.02 \pm 0.02$ \\
\hline (b) $1 / 2\left[\mathrm{O}_{3}\right]$ & & & & & \\
\hline I & $3.5 \pm 1.2$ & $0.04 \pm 0.04$ & $0.46 \pm 0.17$ & $0.47 \pm 0.20$ & $0.02 \pm 0.02$ \\
II & $1.2 \pm 0.3$ & $0.25 \pm 0.11$ & $0.65 \pm 0.09$ & $0.10 \pm 0.04$ & $0.01 \pm 0.01$ \\
III & $1.7 \pm 1.0$ & $0.17 \pm 0.08$ & $0.63 \pm 0.14$ & $0.17 \pm 0.16$ & $0.03 \pm 0.03$ \\
IV & $1.1 \pm 0.4$ & $0.31 \pm 0.16$ & $0.56 \pm 0.16$ & $0.08 \pm 0.05$ & $0.03 \pm 0.03$ \\
\hline Total & $1.8 \pm 1.2$ & $0.20 \pm 0.14$ & $0.58 \pm 0.15$ & $0.19 \pm 0.19$ & $0.02 \pm 0.03$ \\
\hline
\end{tabular}

\begin{tabular}{llllll}
\hline (c) $2\left[\mathrm{H}_{2} \mathrm{O}_{2}\right]$ & & & & & \\
\hline I & $2.7 \pm 1.0$ & $0.03 \pm 0.03$ & $0.60 \pm 0.16$ & $0.35 \pm 0.18$ & $0.02 \pm 0.02$ \\
II & $0.9 \pm 0.2$ & $0.21 \pm 0.10$ & $0.72 \pm 0.09$ & $0.06 \pm 0.03$ & $0.01 \pm 0.01$ \\
III & $1.4 \pm 0.8$ & $0.15 \pm 0.07$ & $0.70 \pm 0.13$ & $0.12 \pm 0.14$ & $0.03 \pm 0.03$ \\
IV & $1.0 \pm 0.3$ & $0.27 \pm 0.15$ & $0.61 \pm 0.16$ & $0.07 \pm 0.03$ & $0.03 \pm 0.03$ \\
\hline Total & $1.4 \pm 0.9$ & $0.17 \pm 0.13$ & $0.66 \pm 0.14$ & $0.14 \pm 0.15$ & $0.02 \pm 0.03$ \\
\hline
\end{tabular}

\begin{tabular}{llllll}
\hline (d) $1 / 2$ clouds & & & & \\
\hline I & $3.7 \pm 1.1$ & $0.06 \pm 0.05$ & $0.42 \pm 0.14$ & $0.50 \pm 0.18$ & $0.02 \pm 0.03$ \\
II & $1.1 \pm 0.3$ & $0.31 \pm 0.12$ & $0.58 \pm 0.11$ & $0.10 \pm 0.04$ & $0.01 \pm 0.01$ \\
III & $1.9 \pm 1.0$ & $0.23 \pm 0.10$ & $0.53 \pm 0.13$ & $0.19 \pm 0.15$ & $0.04 \pm 0.04$ \\
IV & $1.1 \pm 0.5$ & $0.39 \pm 0.18$ & $0.45 \pm 0.16$ & $0.09 \pm 0.07$ & $0.03 \pm 0.03$ \\
\hline Total & $1.8 \pm 1.2$ & $0.26 \pm 0.17$ & $0.50 \pm 0.15$ & $0.20 \pm 0.19$ & $0.03 \pm 0.03$ \\
\hline
\end{tabular}

(e) Low cloud $\mathrm{pH}$

\begin{tabular}{llllll}
\hline I & $1.3 \pm 0.4$ & $0.07 \pm 0.03$ & $0.81 \pm 0.09$ & $0.08 \pm 0.06$ & $0.03 \pm 0.04$ \\
II & $0.6 \pm 0.1$ & $0.26 \pm 0.10$ & $0.72 \pm 0.10$ & $0.01 \pm 0.00$ & $0.01 \pm 0.01$ \\
III & $1.4 \pm 0.5$ & $0.18 \pm 0.07$ & $0.68 \pm 0.10$ & $0.10 \pm 0.05$ & $0.03 \pm 0.04$ \\
IV & $1.1 \pm 0.4$ & $0.30 \pm 0.16$ & $0.57 \pm 0.17$ & $0.08 \pm 0.06$ & $0.03 \pm 0.03$ \\
\hline Total & $1.1 \pm 0.5$ & $0.21 \pm 0.13$ & $0.69 \pm 0.14$ & $0.07 \pm 0.06$ & $0.02 \pm 0.03$ \\
\hline
\end{tabular}

\subsubsection{Cloud fraction sensitivity simulations}

To assess the uncertainty regarding the modeled cloud amount, we perform a sensitivity study by halving the cloud fraction in the model. As in-cloud $\mathrm{S}(\mathrm{IV})$ oxidation by $\mathrm{H}_{2} \mathrm{O}_{2}$ and $\mathrm{O}_{3}$ produces sulfate with $\Delta^{17} \mathrm{O}>0$, a decrease in cloud fraction can potentially reduce $\Delta^{17} \mathrm{O}_{\bmod }\left(\mathrm{nsSSO}_{4}^{2-}\right)$ by reducing in-cloud sulfate formation.

Figure $3 \mathrm{e}$ shows the comparison between $\Delta^{17} \mathrm{O}_{\text {mod }}\left(\mathrm{nssSO}_{4}^{2-}\right)$ and $\Delta^{17} \mathrm{O}_{\text {obs }}\left(\mathrm{nssSO}_{4}^{2-}\right)$ for the sensitivity simulation where cloud fraction is halved. The discrepancy between the model and observations is similar to that in the standard run. Averaged $\Delta^{17} \mathrm{O}_{\bmod }\left(\mathrm{nssSO}_{4}^{2-}\right)$ for samples in different categories are shown in Table 3d. Compared to the standard run, averaged $\Delta^{17} \mathrm{O}_{\bmod }\left(\mathrm{nssSO}_{4}^{2-}\right)$ for all samples changes less than $0.1 \%$. Halving cloud fraction results in a decrease in $f_{\text {mod,aq }}$ from 0.77 to 0.70 and an increase in $f_{\text {mod,OH }}$ from 0.20 to 0.26 . The change in $f_{\text {mod, } \mathrm{O}_{3}}$ is less than 0.01. A large decrease in $f_{\text {mod, } \mathrm{O}_{3}}$ is not observed by halving cloud fraction because lowering aqueous-phase sulfate production rates results in higher cloud $\mathrm{pH}$, shifting the relative importance of $\mathrm{H}_{2} \mathrm{O}_{2}$ and $\mathrm{O}_{3}$ oxidation in the aqueous phase. Halving the cloud amount thus does not 
resolve the discrepancy between $\Delta^{17} \mathrm{O}_{\text {mod }}\left(\mathrm{nssSO}_{4}^{2-}\right)$ and $\Delta^{17} \mathrm{O}_{\mathrm{obs}}\left(\mathrm{nssSO}_{4}^{2-}\right)$.

\subsubsection{Cloud pH sensitivity simulations}

Previous work has shown that bulk cloud models tend to underestimate sulfate formed via the $\mathrm{O}_{3}$ pathway by underestimating $\mathrm{pH}$ and thus underestimating the fraction of $\mathrm{S}(\mathrm{IV})$ that is in the form of $\mathrm{SO}_{3}^{2-}$. Yuen et al. (1996) developed a parameterization to correct for the underestimate in cloud pH by comparing a bulk cloud model with a cloud model that resolves the heterogeneity in cloud chemistry. The uncertainty in this parameterization, and thus the degree to which it might result in an overestimate of the contribution of $\mathrm{O}_{3}$ to in-cloud sulfate formation in GEOS-Chem, is difficult to assess. We perform a sensitivity study that neglects heterogeneity in cloud chemistry by turning off the Yuen et al. (1996) parameterization. By using only bulk cloud $\mathrm{pH}$ calculations, this is effectively a lower limit for cloud $\mathrm{pH}$, and thus is a lower limit for the contribution of $\mathrm{O}_{3}$ to in-cloud sulfate formation in the model in the absence of HOX.

Figure $3 \mathrm{f}$ shows the comparison between $\Delta^{17} \mathrm{O}_{\text {mod }}\left(\mathrm{nssSO}_{4}^{2-}\right)$ and $\Delta^{17} \mathrm{O}_{\text {obs }}\left(\mathrm{nssSO}_{4}^{2-}\right)$ for this low cloud $\mathrm{pH}$ simulation. Overall, $\Delta^{17} \mathrm{O}_{\text {mod }}\left(\mathrm{nssSO}_{4}^{2-}\right)$ matches $\Delta^{17} \mathrm{O}_{\text {obs }}\left(\mathrm{nssSO}_{4}^{2-}\right)$ much better than the standard run, especially for samples over Southern Ocean. $\Delta^{17} \mathrm{O}_{\text {mod }}\left(\mathrm{nssSO}_{4}^{2-}\right)$ ranges from 0.4 to $2.4 \%$, with an average of $1.1 \pm 0.5$ $(1 \sigma) \%$. In comparison, $\Delta^{17} \mathrm{O}_{\mathrm{obs}}\left(\mathrm{nssSO}_{4}^{2-}\right)$ ranges from 0.0 to $1.6 \%$, with an average of $0.7 \pm 0.4(1 \sigma) \%$. The difference between averaged $\Delta^{17} \mathrm{O}_{\bmod }\left(\mathrm{nssSO}_{4}^{2-}\right)$ and $\Delta^{17} \mathrm{O}_{\text {obs }}\left(\mathrm{nssSO}_{4}^{2-}\right)(0.4 \%$ o $)$ is just slightly larger than the measurement uncertainty $( \pm 0.3 \%$ ) . Compared to the standard run, $f_{\text {mod, } \mathrm{O}_{3}}(0.07$ vs. 0.20$)$ is much smaller. $f_{\text {mod, } \mathrm{O}_{3}}$ of 0.07 is within the $\mathrm{O}_{3}$ contribution fraction range constrained by the observations $\left(f_{\min , \mathrm{O}_{3}}=0.03, f_{\max , \mathrm{O}_{3}}=0.12\right)$. The decrease of $f_{\text {mod, } \mathrm{O}_{3}}$ is the main reason for the drop in $\Delta^{17} \mathrm{O}_{\text {mod }}\left(\mathrm{nssSO}_{4}^{2-}\right)$. For samples over Southern Ocean, $f_{\text {mod, } \mathrm{O}_{3}}$ decreases from 0.48 to 0.08 and $\Delta{ }^{17} \mathrm{O}_{\text {mod }}\left(\mathrm{nssSO}_{4}^{2-}\right)$ decreases from 3.6 to $1.3 \%$ o correspondingly (Table $3 \mathrm{e}$ ).

Though averaged $\Delta^{17} \mathrm{O}_{\text {mod }}\left(\mathrm{nssSO}_{4}^{2-}\right)$ is not much larger than $\Delta^{17} \mathrm{O}_{\text {obs }}\left(\mathrm{nssSO}_{4}^{2-}\right)$ in the low cloud $\mathrm{pH}$ sensitivity study, the model does a poor job matching observations for samples with $\Delta^{17} \mathrm{O}_{\text {obs }}\left(\mathrm{nssSO}_{4}^{2-}\right)<0.7 \%$; 25 out of 31 samples with $\Delta^{17} \mathrm{O}_{\text {obs }}\left(\mathrm{nssSO}_{4}^{2-}\right)$ smaller than $0.7 \%$ show that $\Delta^{17} \mathrm{O}_{\text {mod }}\left(\mathrm{nssSO}_{4}^{2-}\right)$ overestimates $\Delta^{17} \mathrm{O}_{\text {obs }}\left(\mathrm{nssSO}_{4}^{2-}\right)$ by more than $50 \%(0.9 \%)$, which indicates the model's inability to produce sulfate with low $\Delta{ }^{17} \mathrm{O}$ even while underestimating cloud $\mathrm{pH}$. The majority of the discrepancy occurs for samples in the Southern Ocean (Catogory I) and subtropical MBL (Catogory III).

\subsubsection{Contribution of HOX oxidation to sulfate formation}

We can estimate the fractional contribution of HOX ( $\left.f_{\text {obs,HOX }}\right)$ to total sulfate abundance necessary to explain the low $\Delta^{17} \mathrm{O}_{\text {obs }}\left(\mathrm{nssSO}_{4}^{2-}\right)$ by comparing modeled $\Delta^{17} \mathrm{O}\left(\mathrm{nssSO}_{4}^{2-}\right)$ with observations. $f_{\mathrm{obs}, \mathrm{HOX}}$ is calculated as shown below:

$f_{\text {obs }, \mathrm{HOX}}=1-\frac{\Delta^{17} \mathrm{O}_{\mathrm{obs}}\left(\mathrm{nssSO}_{4}^{2-}\right)}{\Delta^{17} \mathrm{O}_{\bmod }\left(\mathrm{nssSO}_{4}^{2-}\right)}$.

The derivation of Eq. (8) is described in Appendix A. Calculating $f_{\text {obs, HOX }}$ using Eq. (8) may overestimate $f_{\text {obs, HOX, as it }}$ assumes that the addition of "S(IV) + HOX" will not impact cloud $\mathrm{pH}$. We estimate that this assumption overestimates calculation of $f_{\text {obs,HOX }}$ by about $15 \%$ (see Appendix A).

For $\Delta^{17} \mathrm{O}_{\text {mod }}\left(\mathrm{nssSO}_{4}^{2-}\right)$ in Eq. (8), we use results from both the standard run in Sect. 4.2 and the low cloud $\mathrm{pH}$ run in Sect. 5.2.3 to place bounds on $f_{\text {obs, HOX }}$, using the low cloud $\mathrm{pH}$ sensitivity study as a lower limit for $f_{\text {obs, HOX }}$. We assume $f_{\text {obs, } \mathrm{HOX}}=0$ when $\Delta^{17} \mathrm{O}_{\text {obs }}\left(\mathrm{nssSO}_{4}^{2-}\right)>$ $\Delta^{17} \mathrm{O}_{\text {mod }}\left(\mathrm{nssSO}_{4}^{2-}\right)$ (12 samples in the standard run and 22 samples in the low cloud $\mathrm{pH}$ run). $f_{\text {obs, HOX }}$ for each sample is shown in Fig. 4 for both runs. The averaged $f_{\text {obs, HOX }}$ is shown for samples in each category in Table $4 \mathrm{a}$ (standard run) and $4 \mathrm{~b}$ (low cloud $\mathrm{pH}$ run). Among all samples, averaged $f_{\text {obs,HOX }}$ is $0.50 \pm 0.33$ for the standard run and $0.33 \pm 0.32$ for the low cloud $\mathrm{pH}$ run. $f_{\mathrm{obs}, \mathrm{HOX}}$ is largest for samples over the Southern Ocean (0.58-0.84 on average), followed by the subtropical MBL (0.36-0.47 on average). $f_{\text {obs, HOX }}$ is lowest for samples collected near tropical coasts in the standard run (0.35) and near the Antarctic coast in the low cloud $\mathrm{pH}$ run (0.18).

We can estimate the concentration of HOX needed to achieve $f_{\text {obs, HOX }}$ using Eq. (9) below. The derivation of Eq. (9) is described in Appendix A.

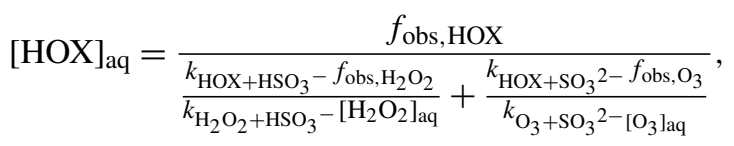

where $k_{\mathrm{H}_{2} \mathrm{O}_{2}+\mathrm{HSO}_{3}{ }^{-}}=2.4 \times 10^{3} \mathrm{M}^{-1} \mathrm{~s}^{-1}$ at $\mathrm{pH}=4.5$ and $\quad k_{\mathrm{O}_{3}+\mathrm{SO}_{3}{ }^{2-}}=1.5 \times 10^{9} \mathrm{M}^{-1} \mathrm{~s}^{-1} . \quad k_{\mathrm{HOBr}+\mathrm{SO}_{3}^{2-}}=$ $5 \times 10^{9} \mathrm{M}^{-1} \mathrm{~s}^{-1}$ and $k_{\mathrm{HOCl}}+\mathrm{SO}_{3}^{2-}=7.6 \times 10^{8} \mathrm{M}^{-1} \mathrm{~s}^{-1}$ are from Fogelman et al. (1989) and Troy and Margerum (1991), respectively. We assume $k_{\mathrm{HOX}+\mathrm{SO}_{3}{ }^{2-}}=2.9 \times 10^{9} \mathrm{M}^{-1} \mathrm{~s}^{-1}$ as the average of $k_{\mathrm{HOBr}+\mathrm{SO}_{3}^{2-}} \quad\left(=5 \times 10^{9} \mathrm{M}^{-1} \mathrm{~s}^{-1}\right.$, Troy and Margerum, 1991) and $k_{\mathrm{HOCl}}+\mathrm{SO}_{3}^{2-}(=$ $7.6 \times 10^{8} \mathrm{M}^{-1} \mathrm{~s}^{-1}$, Fogelman et al., 1989). We assume $k_{\mathrm{HOX}+\mathrm{HSO}_{3}{ }^{-}}=2.0 \times 10^{9} \mathrm{M}^{-1} \mathrm{~s}^{-1}$ which is the average of 
Table 4. $f_{\mathrm{obs}, \mathrm{HOX}},[\mathrm{HOX}]_{\mathrm{aq}}$ and $[\mathrm{HOX}]_{\mathrm{g}}$ calculated using the model results from (a) the standard run and (b) low cloud pH run, respectively. The mean and standard deviation are shown for $f_{\mathrm{obs}, \mathrm{HOX}}$. The range and median value are shown for $[\mathrm{HOX}]_{\mathrm{aq}}$ and $[\mathrm{HOX}]_{\mathrm{g}}$.

\begin{tabular}{llll|lll}
\hline Category & \multicolumn{3}{c|}{ (a) Standard run } & \multicolumn{3}{c}{ (b) Low cloud pH } \\
\cline { 2 - 7 } & $f_{\text {obs, HOX }}$ & {$[\mathrm{HOX}]_{\mathrm{aq}}(\mathrm{pM})$} & {$[\mathrm{HOX}]_{\mathrm{g}}(\mathrm{ppt})$} & $f_{\text {obs, HOX }}$ & {$[\mathrm{HOX}]_{\mathrm{aq}}(\mathrm{pM})$} & {$[\mathrm{HOX}]_{\mathrm{g}}(\mathrm{ppt})$} \\
\hline I & $0.84 \pm 0.15$ & $41-30192(102)$ & $0.04-30.97(0.10)$ & $0.58 \pm 0.30$ & $1-4048(27)$ & $0.00-4.15(0.03)$ \\
II & $0.42 \pm 0.29$ & $0-395(26)$ & $0.00-0.40(0.03)$ & $0.18 \pm 0.26$ & $0-145(0)$ & $0.00-0.15(0.00)$ \\
III & $0.47 \pm 0.34$ & $0-3334(97)$ & $0.00-3.42(0.10)$ & $0.36 \pm 0.32$ & $0-2585(40)$ & $0.00-2.65(0.04)$ \\
IV & $0.35 \pm 0.29$ & $0-761(85)$ & $0.00-0.78(0.09)$ & $0.28 \pm 0.31$ & $0-764(54)$ & $0.00-0.78(0.06)$ \\
\hline Total & $0.50 \pm 0.33$ & $0-30192(88)$ & $0.00-30.97(0.09)$ & $0.33 \pm 0.32$ & $0-4048(11)$ & $0.00-4.15(0.01)$ \\
\hline
\end{tabular}

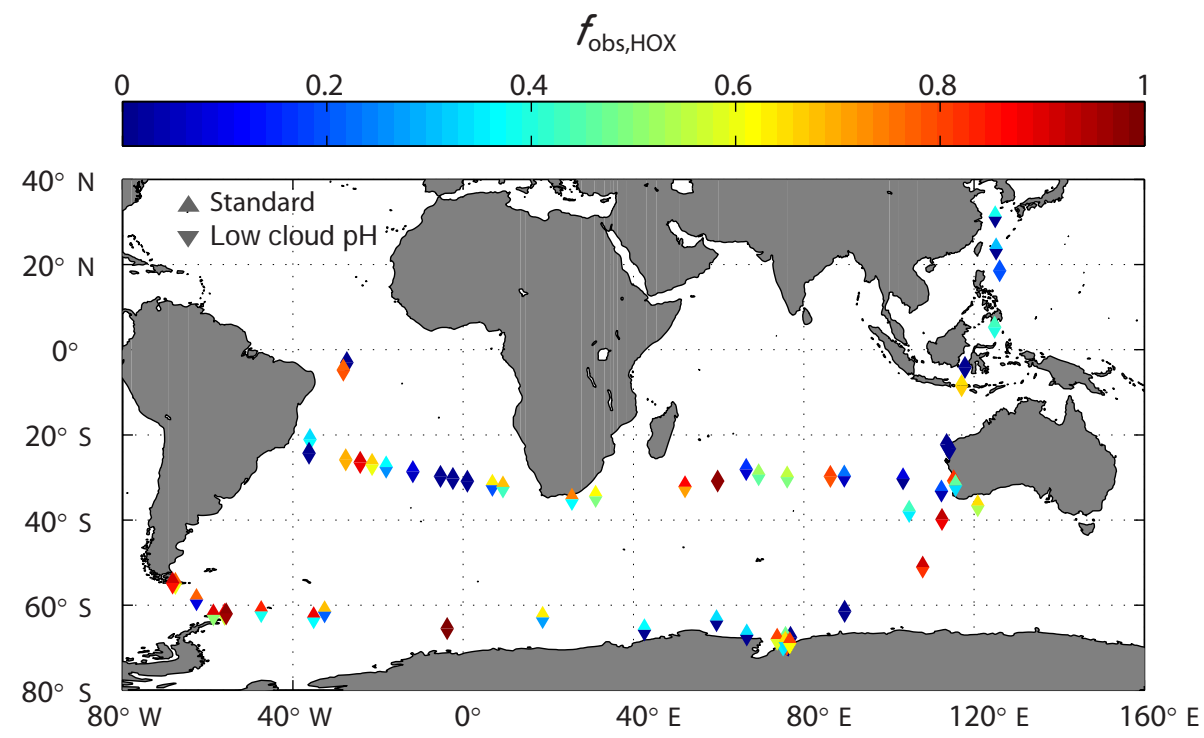

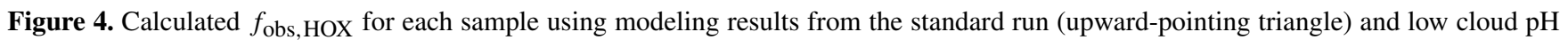
run (downward-pointing triangle), respectively.

$k_{\mathrm{HOBr}+\mathrm{HSO}_{3}^{-}}\left(=3.2 \times 10^{9} \mathrm{M}^{-1} \mathrm{~s}^{-1}\right.$ upper limit from Liu, $2000)$ and $k_{\mathrm{HOCl}+\mathrm{HSO}_{3}-}\left(=k_{\mathrm{HOCl}}+\mathrm{SO}_{3}^{2-}\right.$, as assumed by Vogt et al. (1996) and von Glasow et al., 2002). $f_{\text {obs, HOX is }}$ calculated from Eq. (8), and $f_{\mathrm{obs}, \mathrm{H}_{2} \mathrm{O}_{2}}$ and $f_{\mathrm{obs}, \mathrm{O}_{3}}$ are calculated from Eqs. (A9) and (A14) using the same assumption as $f_{\text {obs, } \mathrm{HOX}}$ (see Appendix A). $\left[\mathrm{H}_{2} \mathrm{O}_{2}\right]_{\mathrm{aq}}$ and $\left[\mathrm{O}_{3}\right]_{\mathrm{aq}}$ are obtained from the model, and range from 2 to $172 \mu \mathrm{M}$ and $113-463 \mathrm{pM}$, respectively. The range and median value of $[\mathrm{HOX}]_{\mathrm{aq}}$ for samples in different categories are shown in Table 4. $[\mathrm{HOX}]_{\mathrm{aq}}$ needed to explain $f_{\mathrm{obs}, \mathrm{HOX}}$ is on the order of 100 and $10 \mathrm{pM}$ for the standard run and low cloud $\mathrm{pH}$ run, respectively. By assuming the Henry's law constant $H_{\mathrm{HOX}}$ of $975 \mathrm{M} \mathrm{atm}^{-1}$ (average between $H_{\mathrm{HOCl}}$ and $H_{\mathrm{HOBr}}$ from Huthwelker et al., 1995, and Sander et al., 2006), the daily-averaged gas-phase $[\mathrm{HOX}]$ mixing ratio $[\mathrm{HOX}]_{\mathrm{g}}$ is calculated and shown in Table 4. Due to the low solubility of HOX, under typical atmospheric conditions, more than $99 \%$ of total HOX is in the gas phase. Daily-averaged $[\mathrm{HOX}]_{\mathrm{g}}$ is on the order of 0.1 and $0.01 \mathrm{ppt}$ when using $f_{\mathrm{obs}, \mathrm{HOX}}$ from the standard run and low cloud $\mathrm{pH}$ run, respectively. Thus, a gas-phase HOX mixing ratio of $\approx 0.1 \mathrm{ppt}$ or higher would be sufficient to explain the observed $\Delta^{17} \mathrm{O}\left(\mathrm{nssSO}_{4}^{2-}\right)$ of our samples. Uncertainties in our calculated $[\mathrm{HOX}]_{\mathrm{g}}$ can originate from (1) uncertainties in the rate constant for reaction between $\mathrm{HOX}$ and $\mathrm{HSO}_{3}^{-}\left(k_{\mathrm{HOX}+\mathrm{HSO}_{3}-}\right)$, (2) uncertainties in the Henry's law constant for HOX $\left(H_{\mathrm{HOX}}\right)$ and (3) the efficiency of reactive uptake of gas-phase HOX onto cloud droplets that is not accounted for in our assumption of equilibrium of HOX between the gas and aqueous phase.

In comparison, a box-modeling study by Vogt et al. (1996) estimated that daytime-averaged $[\mathrm{HOX}]_{\mathrm{g}}$ on the order of $10 \mathrm{ppt}$ is needed to achieve a similar fraction $(\approx 60 \%)$ of sulfate formed via HOX oxidation. The difference in $[\mathrm{HOX}]_{\mathrm{g}}$ between our study and Vogt et al. (1996) is caused by several factors. First, $H_{\mathrm{HOBr}}$ in our calculations is an order of magnitude larger than that in Vogt et al. (1996), so that our calculations require an order of magnitude lower $[\mathrm{HOBr}]_{\mathrm{g}}$ to produce the same aqueous-phase concentration. Second, $\mathrm{H}_{2} \mathrm{O}_{2}$ and $\mathrm{O}_{3}$ mixing ratios in our calculations (Eq. 9) are 
lower than those in Vogt et al. (1996) (0.6 vs. $0.8 \mathrm{ppt}$ for $\left[\mathrm{H}_{2} \mathrm{O}_{2}\right]$ and 18 vs. $40 \mathrm{ppt}$ for $\left.\left[\mathrm{O}_{3}\right]\right)$, so that higher $[\mathrm{HOBr}]_{\mathrm{g}}$ is needed in Vogt et al. (1996) to compete with S(IV) oxidation by $\mathrm{H}_{2} \mathrm{O}_{2}$ and $\mathrm{O}_{3}$. Third, in our simple calculation we assume equilibrium of HOX between the gas and aqueous phase, while Vogt et al. (1996) consider all mass transfer limitations. Higher $[\mathrm{HOX}]_{\mathrm{g}}$ will be calculated if diffusion and subsequent mass accommodation of gas-phase HOX onto the cloud droplets is not fast enough to compensate for the loss of HOX from aqueous-phase chemistry. Fourth, $[\mathrm{HOX}]_{\mathrm{g}}$ on the order of $0.1 \mathrm{ppt}$ calculated in our study is a daily-averaged concentration, while $[\mathrm{HOX}]_{\mathrm{g}}$ on the order of $10 \mathrm{ppt}$ in Vogt et al. (1996) is a daytime-averaged concentration, and hence are not directly comparable. Vogt et al. (1996) has shown that nighttime-averaged $[\mathrm{HOX}]_{\mathrm{g}}$ is about 2 orders of magnitude lower than daytime-averaged $[\mathrm{HOX}]_{\mathrm{g}}$.

The daily-averaged $\mathrm{HOBr}$ mixing ratio over the Southern Ocean $\left(40-64^{\circ} \mathrm{S}\right.$, below $\left.100 \mathrm{~m}\right)$ modeled by Schmidt et al. (2016) varied from $0.1-0.3$ to $0.2-0.4 \mathrm{ppt}$ for simulations without and with debromination from acidic sea-salt aerosol, respectively. The HOX mixing ratio on the order of $0.1 \mathrm{ppt}$ calculated from $\Delta^{17} \mathrm{O}\left(\mathrm{nssSO}_{4}^{2-}\right)$ of our samples using standard run results is consistent with that obtained in Schmidt et al. (2016).

Comparison of our calculated daily-averaged HOX mixing ratios with observations is difficult, as HOX is expected to show significant diurnal variability (on the order of $2 \mathrm{ppt}$ ), with mixing ratios near zero at night and peaking at around noon (von Glasow et al., 2002). A daytimeaveraged $\mathrm{HOBr}$ mixing ratio of about $10 \mathrm{ppt}$ was observed by Liao et al. (2012) at Alaska in spring, which is about 2-3 orders of magnitude higher than our calculated dailyaveraged $[\mathrm{HOX}]_{\mathrm{g}}$. The nighttime $\mathrm{HOBr}$ mixing ratio in their study was below the detection limit of about 2 ppt. This is much higher than our calculated daily-averaged $[\mathrm{HOX}]_{\mathrm{g}}$, but it is likely that $\mathrm{HOBr}$ mixing ratios could vary significantly with sampling locations and sampling time (Schmidt et al., 2016). Field campaigns of HOX measurements are necessary to assess our calculated HOX mixing ratios over our sampling regions.

\section{Conclusions}

This study uses a combination of observations and modeling of $\Delta^{17} \mathrm{O}\left(\mathrm{nssSO}_{4}^{2-}\right)$ to quantify the role of $\mathrm{HOX}$ $(=\mathrm{HOBr}+\mathrm{HOCl})$ in sulfate formation in the remote MBL. Samples collected over a wide spatial range in the MBL during spring and summer show low $\Delta^{17} \mathrm{O}_{\text {obs }}\left(\mathrm{nssSO}_{4}^{2-}\right)$ $(0.7 \pm 0.4 \%$ ), which suggests that only $3-12 \%$ of sulfate is formed via $\mathrm{O}_{3}$ oxidation. The standard model run overestimates $\Delta^{17} \mathrm{O}_{\text {obs }}\left(\mathrm{nsSSO}_{4}^{2-}\right)$ by about a factor of 2.5 on average because it overestimates the amount of sulfate formed by $\mathrm{O}_{3}$ in the aqueous phase. This discrepancy could not be resolved by either varying oxidant concentrations, halving cloud amount or using a lower limit for cloud $\mathrm{pH}$ in the model. Our calculations suggest that the discrepancy can be explained with a fractional contribution of sulfate abundance formed by HOX ranging from 33 to $50 \%$ over the entire area sampled, with the highest fraction (58-84\%) in the Southern Ocean MBL. A daily-averaged gas-phase HOX mixing ratio of $\approx 0.1 \mathrm{ppt}$ or higher would be sufficient to explain the observed $\Delta^{17} \mathrm{O}\left(\mathrm{nssSO}_{4}^{2-}\right)$ of our samples. This study provides the first observational constraint on the role of hypohalous acids in sulfate aerosol formation in the MBL. Future studies will implement the "S(IV) + HOX" reaction in GEOS-Chem to investigate the impacts of this reaction on the global sulfur budget and possible feedbacks on acid-catalyzed reactive halogen production.

\section{Data availability}

All laboratory measurement data used in this study (aerosol ion concentrations and oxygen-17 excess of sulfate) are permanently archived at the University of Washington ResearchWorks site: https://digital.lib.washington.edu/researchworks/ handle/1773/36944 (Chen, 2016). 


\section{Appendix A}

Hitherto, there has been no observational constraint on HOX mixing ratios in the mid- and high-latitude remote MBL. Models have suggested a large range of HOX mixing ratios on the order of $0.1 \mathrm{ppt}$ (Schmidt et al., 2016) to $10 \mathrm{ppt}$ (Vogt et al., 1996) over these regions. Here we quantify the daily-averaged HOX mixing ratio indirectly from observed and modeled $\Delta^{17} \mathrm{O}$ of sulfate. First, we calculate the fractional contribution of the HOX oxidation pathway ( $f_{\text {obs, HOX }}$ ) to sulfate abundance in our samples. Then, we calculate the HOX mixing ratio needed to achieve this $f_{\text {obs, HOX }}$.

\section{A1 Calculation of $f_{\text {obs, HOX }}$}

We assume all modeled sulfate in the MBL is formed via gasphase $\mathrm{OH}$ oxidation and aqueous-phase $\mathrm{H}_{2} \mathrm{O}_{2}$ or $\mathrm{O}_{3}$ oxidation based on the insignificant contribution $(<3 \%)$ of other sulfate sources in the model.

$f_{\text {mod }, \mathrm{OH}}+f_{\text {mod }, \mathrm{H}_{2} \mathrm{O}_{2}}+f_{\text {mod }, \mathrm{O}_{3}}=1$,
$a f_{\text {mod }, \mathrm{H}_{2} \mathrm{O}_{2}}+b f_{\text {mod }, \mathrm{O}_{3}}=\Delta^{17} \mathrm{O}_{\bmod }\left(\mathrm{nssSO}_{4}^{2-}\right)$,

where $\quad a=\Delta^{17} \mathrm{O}\left(\mathrm{nssSO}_{4}^{2-}\right) \mathrm{H}_{2} \mathrm{O}_{2}=0.7 \%$ and $b=$ $\Delta^{17} \mathrm{O}\left(\mathrm{nssSO}_{4}^{2-}\right)_{\mathrm{O}_{3}}=6.5 \%$. For the observations, we assume all sulfate in the MBL is formed via gas-phase $\mathrm{OH}$ oxidation, aqueous-phase $\mathrm{H}_{2} \mathrm{O}_{2}, \mathrm{O}_{3}$ and $\mathrm{HOX}$ oxidation pathways:

$f_{\text {obs }, \mathrm{OH}}+f_{\text {obs }, \mathrm{H}_{2} \mathrm{O}_{2}}+f_{\mathrm{obs}, \mathrm{O}_{3}}+f_{\text {obs }, \mathrm{HOX}}=1$,

$a f_{\mathrm{obs}, \mathrm{H}_{2} \mathrm{O}_{2}}+b f_{\mathrm{obs}, \mathrm{O}_{3}}=\Delta^{17} \mathrm{O}_{\mathrm{obs}}\left(\mathrm{nssSO}_{4}^{2-}\right)$,

where $f_{\text {obs, } \mathrm{OH}}, f_{\text {obs, } \mathrm{H}_{2} \mathrm{O}_{2}}, f_{\text {obs, } \mathrm{O}_{3}}$ and $f_{\text {obs, HOX }}$ are the observed fractions of sulfate formed via gas-phase $\mathrm{OH}$, aqueous-phase $\mathrm{H}_{2} \mathrm{O}_{2}, \mathrm{O}_{3}$ and $\mathrm{HOX}$ oxidation pathways, respectively. To solve for $f_{\mathrm{obs}, \mathrm{HOX}}$, two more equations involving $f_{\text {obs }, \mathrm{OH}}, f_{\text {obs, } \mathrm{H}_{2} \mathrm{O}_{2}}, f_{\text {obs, } \mathrm{O}_{3}}$ and $f_{\text {obs, } \mathrm{HOX}}$ are needed, in addition to Eqs. (A3)-(A4). Here we assume $f_{\text {obs }, \mathrm{O}_{3}} / f_{\text {obs }, \mathrm{H}_{2} \mathrm{O}_{2}}$ ratio is offset from $f_{\text {mod, } \mathrm{O}_{3}} / f_{\text {mod, } \mathrm{H}_{2} \mathrm{O}_{2}}$ ratio by $\Delta r_{1}$ and $f_{\mathrm{obs}, \mathrm{OH}} / f_{\mathrm{obs}, \mathrm{H}_{2} \mathrm{O}_{2}}$ ratio is offset from $f_{\text {mod, } \mathrm{OH}} / f_{\text {mod, } \mathrm{H}_{2} \mathrm{O}_{2}}$ ratio by $\Delta r_{2}$ :

$$
\begin{aligned}
\frac{f_{\mathrm{obs}, \mathrm{O}_{3}}}{f_{\mathrm{obs}, \mathrm{H}_{2} \mathrm{O}_{2}}} & =\frac{f_{\text {mod, } \mathrm{O}_{3}}}{f_{\text {mod, } \mathrm{H}_{2} \mathrm{O}_{2}}}+\Delta r_{1} \\
\frac{f_{\mathrm{obs}, \mathrm{OH}}}{f_{\mathrm{obs}, \mathrm{H}_{2} \mathrm{O}_{2}}} & =\frac{f_{\text {mod, } \mathrm{OH}}}{f_{\text {mod, } \mathrm{H}_{2} \mathrm{O}_{2}}}+\Delta r_{2}
\end{aligned}
$$

Combining Eqs. (A3)-(A6) and using Eqs. (A1)-(A2) yield

$$
f_{\mathrm{obs}, \mathrm{HOX}}=1-\frac{\Delta^{17} \mathrm{O}_{\mathrm{obs}}\left(\mathrm{nssSO}_{4}^{2-}\right)}{\Delta^{17} \mathrm{O}_{\mathrm{mod}}\left(\mathrm{nssSO}_{4}^{2-}\right)}+\Delta f
$$

where

$\Delta f=$

$f_{\mathrm{obs}, \mathrm{H}_{2} \mathrm{O}_{2}}\left[\left(\frac{b}{\Delta^{17} \mathrm{O}_{\mathrm{mod}}\left(\mathrm{nssSO}_{4}^{2-}\right)}-1\right) \Delta r_{1}-\Delta r_{2}\right]$

and

$f_{\mathrm{obs}, \mathrm{H}_{2} \mathrm{O}_{2}}=\frac{f_{\mathrm{mod}, \mathrm{H}_{2} \mathrm{O}_{2}} \Delta^{17} \mathrm{O}_{\mathrm{obs}}\left(\mathrm{nssSO}_{4}^{2-}\right)}{\Delta^{17} \mathrm{O}_{\bmod }\left(\mathrm{nssSO}_{4}^{2-}\right)+b \Delta r_{1} f_{\mathrm{mod}, \mathrm{H}_{2} \mathrm{O}_{2}}}$.

Setting $\Delta f=0$ yields Eq. (8) in Sect. 5.2.4. $\Delta f$ is zero when $\Delta r_{1}=\Delta r_{2}=0$, which effectively assumes that the decreases in $f_{\text {mod,OH }}, f_{\text {mod, } \mathrm{H}_{2} \mathrm{O}_{2}}$ and $f_{\text {mod, } \mathrm{O}_{3}}$ after adding $\mathrm{HOX}$ in the model could be proportional to their relative fractions in the model. $\Delta r_{1}$ will be zero if cloud $\mathrm{pH}$ is unchanged; i.e., the $\mathrm{S}$ (IV) partitioning will remain unchanged after adding the "S(IV) + HOX" reaction. The potential magnitude of $\Delta f$, which is dependent on the relative magnitude of $\Delta r_{1}$ and $\Delta r_{2}$, is discussed below.

$\Delta r_{1}$ is expected to be negative with the addition of "S(IV) + HOX" reaction. Additional sulfate production in the aqueous phase will decrease cloud $\mathrm{pH}$, resulting in decreases in the fractional contribution of $\mathrm{O}_{3}$ relative to $\mathrm{H}_{2} \mathrm{O}_{2}\left(f_{\mathrm{O}_{3}} / f_{\mathrm{H}_{2} \mathrm{O}_{2}}\right)$. The magnitude of the potential decrease in cloud $\mathrm{pH}$ can only be obtained after adding the "S(IV) + HOX" reactions in the model, which will be done in a follow-up study.

$\Delta r_{2}$ is expected to be positive with the addition of "S(IV) + HOX" reaction. HOX competes with $\mathrm{H}_{2} \mathrm{O}_{2}$ during oxidation of $\mathrm{HSO}_{3}^{-}$in clouds, which causes a direct decrease in the fraction of sulfate formed via $\mathrm{H}_{2} \mathrm{O}_{2}$ oxidation $\left(f_{\text {mod, } \mathrm{H}_{2} \mathrm{O}_{2}}\right)$. On the other hand, gas-phase sulfate production from oxidation of $\mathrm{SO}_{2}$ by $\mathrm{OH}$ occurs mainly in the absence of clouds. Thus, adding "S(IV) + HOX" reaction causes an indirect decrease in the fraction of sulfate formed via $\mathrm{OH}$ oxidation $\left(f_{\text {mod,OH }}\right)$ by increasing in-cloud and consequent total sulfate production, which depends on the availability of S(IV). Our model indicates that in-cloud sulfate production is limited by $\mathrm{S}(\mathrm{IV})$ abundance among our sampling locations (see the doubling $\mathrm{H}_{2} \mathrm{O}_{2}$ and $\mathrm{O}_{3}$ simulation below), such that the decrease of $f_{\text {mod,OH }}$ is small compared to that of $f_{\mathrm{mod}, \mathrm{H}_{2} \mathrm{O}_{2}}$ with the addition of " $\mathrm{S}(\mathrm{IV})+\mathrm{HOX}$ " reaction, which results in an increase in the fractional contribution of $\mathrm{OH}$ relative to $\mathrm{H}_{2} \mathrm{O}_{2}\left(f_{\mathrm{OH}} / f_{\mathrm{H}_{2} \mathrm{O}_{2}}\right)$.

As $\quad \Delta^{17} \mathrm{O}_{\bmod }\left(\mathrm{nssSO}_{4}^{2-}\right)<b, \quad$ the term $\left(\frac{b}{\Delta^{17} \mathrm{O}_{\text {mod }}\left(\mathrm{nssSO}_{4}^{2-}\right)}-1\right)$ is positive. In addition, $f_{\mathrm{obs}, \mathrm{H}_{2} \mathrm{O}_{2}}$ is positive. Thus, $\Delta f$ is likely a negative number, which indicates Eq. (8) in Sect. 5.2.4 may overestimate $f_{\text {obs, HOX. }}$

We simulate the effect of an additional aqueous-phase reaction ("S $(\mathrm{IV})+\mathrm{HOX}$ ") in the model on $\Delta r_{1}$ and $\Delta r_{2}$ 
by doubling both $\mathrm{H}_{2} \mathrm{O}_{2}$ concentration and $\mathrm{O}_{3}$ concentration. By doing this, we attribute half of the sulfate produced via $\mathrm{H}_{2} \mathrm{O}_{2}$ and $\mathrm{O}_{3}$ oxidation to HOX oxidation. This simulation yields fractional contribution of sulfate formed via gas-phase $\mathrm{OH}$, aqueous-phase $\mathrm{H}_{2} \mathrm{O}_{2}, \mathrm{O}_{3}$ and $\mathrm{HOX}$ oxidation pathways to be $0.17,0.33,0.08$ and 0.40 , respectively, among all sampling locations. Compared to the standard run, $f_{\text {mod, } \mathrm{O}_{3}} / f_{\text {mod, } \mathrm{H}_{2} \mathrm{O}_{2}}$ ratio decreases from 0.35 to 0.23 and $f_{\text {mod, } \mathrm{OH}} / f_{\text {mod, } \mathrm{H}_{2} \mathrm{O}_{2}}$ ratio increases from 0.35 to 0.53 on average among all sampling locations, yielding $\Delta r_{1}=$ -0.12 and $\Delta r_{2}=0.18$. Substituting standard run results $\left(\Delta^{17} \mathrm{O}_{\text {obs }}\left(\mathrm{nssSO}_{4}^{2-}\right)=0.7 \%\right.$ o, $\Delta^{17} \mathrm{O}_{\bmod }\left(\mathrm{nssSO}_{4}^{2-}\right)=1.8 \%$ o and $f_{\text {mod, } \mathrm{H}_{2} \mathrm{O}_{2}}=0.57$; Table 2$)$ and $\Delta r_{1}=-0.12$ and $\Delta r_{2}=$ 0.18 into Eq. (A8)-(A9) yields $\Delta f=-0.15$. Thus, if the addition of "S(IV) + HOX" reaction results in $40 \%$ of sulfate formed via oxidation of S(IV) by HOX, then our esti-

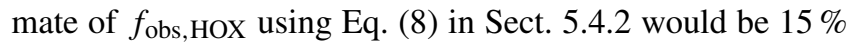
too high. The fraction $(40 \%)$ of sulfate formed via oxidation of S(IV) by HOX is within the range of the averaged $f_{\text {obs, HOX }}(33-50 \%)$ calculated from observed and modeled $\Delta^{17} \mathrm{O}\left(\mathrm{nssSO}_{4}^{2-}\right)$ using Eq. (8). Thus, we suggest that calculating $f_{\text {obs, HOX }}$ for our samples using Eq. (8) may overestimate $f_{\text {obs,HOX }}$ by about $15 \%$. This is smaller than the

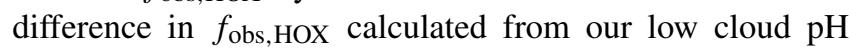
$(0.33 \pm 0.32)$ and standard model $(0.50 \pm 0.33)$ runs. The actual magnitude of $\Delta f$ can only be obtained by implementing the "S(IV) + HOX" reaction in the model.

\section{Appendix B: Calculation of HOX mixing ratios}

We estimate the mixing ratio of HOX needed to achieve $f_{\text {obs, HOX }}$. First, we divide $f_{\text {obs, HOX }}$ into two parts:

$f_{\mathrm{obs}, \mathrm{HOX}}=f_{1, \mathrm{HOX}}+f_{2, \mathrm{HOX}}$,

where $f_{1, \mathrm{HOX}}$ and $f_{2 \text {, HOX }}$ are fractional contributions from

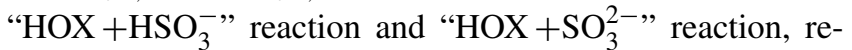
spectively. $\mathrm{H}_{2} \mathrm{O}_{2}$ reacts with $\mathrm{HSO}_{3}^{-}$only and $\mathrm{O}_{3}$ reacts mainly with $\mathrm{SO}_{3}^{2-}$ (Hoffmann and Calvert, 1985), while HOX reacts quickly with both $\mathrm{HSO}_{3}^{-}$and $\mathrm{SO}_{3}^{2-}$. Then we compare $f_{1, \mathrm{HOX}}$ with $f_{\mathrm{obs}, \mathrm{H}_{2} \mathrm{O}_{2}}$ and 2 , $\mathrm{HOX}$ with $f_{\mathrm{obs}, \mathrm{O}_{3}}$ :

$$
\begin{aligned}
& \frac{f_{1, \mathrm{HOX}}}{f_{\mathrm{obs}, \mathrm{H}_{2} \mathrm{O}_{2}}}=\frac{k_{\mathrm{HOX} \mathrm{HSO}_{3}}-[\mathrm{HOX}]_{\mathrm{aq}}}{k_{\mathrm{H}_{2} \mathrm{O}_{2}+\mathrm{HSO}_{3}-\left[\mathrm{H}_{2} \mathrm{O}_{2}\right]_{\mathrm{aq}}}}, \\
& \frac{f_{2, \mathrm{HOX}}}{f_{\mathrm{obs}, \mathrm{O}_{3}}}=\frac{k_{\mathrm{HOX}+\mathrm{SO}_{3}{ }^{2-}[\mathrm{HOX}]_{\mathrm{aq}}}}{k_{\mathrm{O}_{3}+\mathrm{SO}_{3}{ }^{2-}\left[\mathrm{O}_{3}\right]_{\mathrm{aq}}}},
\end{aligned}
$$

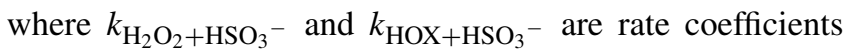
for reactions of $\mathrm{H}_{2} \mathrm{O}_{2}$ and $\mathrm{HOX}$ with $\mathrm{HSO}_{3}^{-}$, respectively;

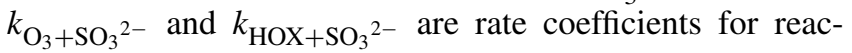
tions of $\mathrm{O}_{3}$ and $\mathrm{HOX}$ with $\mathrm{SO}_{3}^{2-}$, respectively; and $\left[\mathrm{H}_{2} \mathrm{O}_{2}\right]_{\mathrm{aq}}$, $\left[\mathrm{O}_{3}\right]_{\mathrm{aq}}$ and $[\mathrm{HOX}]_{\mathrm{aq}}$ are the aqueous-phase concentrations of $\mathrm{H}_{2} \mathrm{O}_{2}, \mathrm{O}_{3}$ and $\mathrm{HOX}$ in the cloud droplets, respectively. Combining Eqs. (A10)-(A12) yields

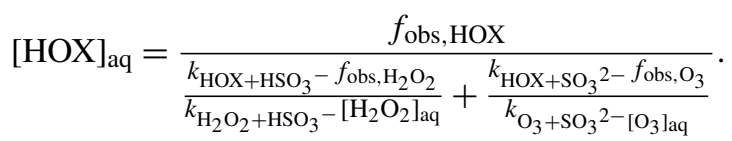

This is the same equation as Eq. (9) in Sect. 5.4.2. $f_{\text {obs, HOX }}$ and $f_{\mathrm{obs}, \mathrm{H}_{2} \mathrm{O}_{2}}$ are calculated in Eqs. (A7) and (A9), respectively. Combining Eqs. (A5) and (A9) yields

$$
f_{\mathrm{obs}, \mathrm{O}_{3}}=\frac{\left(f_{\mathrm{mod}, \mathrm{O}_{3}}+\Delta r_{1} f_{\mathrm{mod}, \mathrm{H}_{2} \mathrm{O}_{2}}\right) \Delta^{17} \mathrm{O}_{\mathrm{obs}}\left(\mathrm{nssSO}_{4}^{2-}\right)}{\Delta^{17} \mathrm{O}_{\bmod }\left(\mathrm{nssSO}_{4}^{2-}\right)+6.5 \Delta r_{1} f_{\text {mod }, \mathrm{H}_{2} \mathrm{O}_{2}}} .
$$

For the calculations of $f_{\mathrm{obs}, \mathrm{HOX}}, f_{\mathrm{obs}, \mathrm{H}_{2} \mathrm{O}_{2}}$ and $f_{\mathrm{obs}, \mathrm{O}_{3}}$ in Sect. 5.4.2, both $\Delta r_{1}$ and $\Delta r_{2}$ are assumed to be zero. 


\section{The Supplement related to this article is available online at doi:10.5194/acp-16-11433-2016-supplement.}

Acknowledgements. We thank Roland von Glasow and Jon Abbatt for helpful discussions in the planning phase of this project. This project is funded by NSF AGS 1343077. The sampling during the Malaspina cruise was funded by the Spanish Ministry of Economy and Competiveness (Circumnavigation Expedition Malaspina 2010: Global Change and Biodiversity Exploration of the Global Ocean. CSD2008-00077). Z. Q. Xie acknowledges the support from NSFC 91544103. Q. Chen thanks Viral Shah for help on GEOS-Chem modeling.

Edited by: E. Harris

Reviewed by: R. Sander and A.-L. Norman

\section{References}

Alexander, B., Park, R. J., Jacob, D. J., Li, Q. B., Yantosca, R. M., Savarino, J., Lee, C. C. W., and Thiemens, M. H.: Sulfate formation in sea salt aerosols: Constraints from oxygen isotopes, J. Geophys. Res., 110, D10307, doi:10.1029/2004JD005659, 2005.

Alexander, B., Park, R. J., Jacob, D. J., and Gong, S.: Transition metal-catalyzed oxidation of atmospheric sulfur: global implications for the sulfur budget, J. Geophys. Res., 114, D02309, doi:10.1029/2008JD010486, 2009.

Alexander, B., Allman, D. J., Amos, H. M., Fairlie, T. D., Dachs, J., Hegg, D. A., and Sletten, R. S.: Isotopic constraints on the formation pathways of sulfate aerosol in the marine boundary layer of the subtropical northeast Atlantic Ocean, J. Geophys. Res., 117, D06304, doi:10.1029/2011JD016773, 2012.

Bao, H. M., Thiemens, M. H., Farquhar, J., Campbell, D. A., Lee, C. C. W., Heine, K., and Loope, D. B.: Anomalous ${ }^{17} \mathrm{O}$ compositions in massive sulphate deposits on the Earth, Nature, 406, 176-178, doi:10.1038/35018052, 2000.

Bates, T. S., Lamb, B. K., Guenther, A., Dignon, J., and Stoiber, R. E.: Sulfur emissions to the atmosphere from natural sources, J. Atmos. Chem., 14, 315-337, doi:10.1007/BF00115242, 1992.

Blatchley III, E. R., Johnson, R. W., Alleman, J. E., and McCoy, W. F.: Effective Henry's law constant for free chlorine and free bromine, Water Res., 26, 99-106, doi:10.1016/00431354(92)90117-M, 1992.

Barkan, E. and Luz, B.: High precision measurements of ${ }^{17} \mathrm{O} /{ }^{16} \mathrm{O}$ and ${ }^{18} \mathrm{O} /{ }^{16} \mathrm{O}$ ratios in $\mathrm{H}_{2} \mathrm{O}$, Rapid Commun. Mass Sp., 19, 3737-3742, doi:10.1002/rcm.2250, 2005.

Boucher, O., Moulin, C., Belviso, S., Aumont, O., Bopp, L., Cosme, E., von Kuhlmann, R., Lawrence, M. G., Pham, M., Reddy, M. S., Sciare, J., and Venkataraman, C.: DMS atmospheric concentrations and sulphate aerosol indirect radiative forcing: a sensitivity study to the DMS source representation and oxidation, Atmos. Chem. Phys., 3, 49-65, doi:10.5194/acp-3-49-2003, 2003.

Carslaw, K. S., Lee, L. A., Reddington, C. L., Pringle, K. J., Rap, A., Forster, P. M., Mann, G. W., Spracklen, D. V., Woodhouse, M. T., Regayre, L. A., and Pierce, J. R.: Large contribution of natural aerosols to uncertainty in indirect forcing, Nature, 503, 67-71, doi:10.1038/nature12674, 2013.
Chameides, W. L. and Stelson, A. W.: Aqueous-phase chemical processes in deliquescent sea-salt aerosols: A mechanism that couples the atmospheric cycles of S and sea-salt, J. Geophys. Res., 97, 20565-20580, doi:10.1029/92JD01923, 1992.

Chin, M., Rood, R. B., Lin, S.-J., Muller, J. F., and Thompson, A. M.: Atmospheric sulfur cycle in the global model GOCART: Model description and global properties, J. Geophys. Res., 105, 24671-24687, doi:10.1029/2000JD900384, 2000.

Cole-Dai, J., Thompson, L. G., and Mosley-Thompson, E.: A 485 year record of atmospheric chloride, nitrate and sulfate: Results of chemical analysis of ice cores from Dyer Plateau, Antarctic Peninsula, Ann. Glaciol., 21, 182-188, 1995.

Dominguez, G., Jackson, T., Brothers, L., Barnett, B., Nguyen, B., and Thiemens, M. H.: Discovery and measurement of an isotopically distinct source of sulfate in Earth's atmosphere, P. Natl. Acad. Sci. USA, 105, 12769-12773, doi:10.1073/pnas.0805255105, 2008.

Dubey, M. K., Mohrschladt, R., Donahue, N. M., and Anderson, J. G.: Isotope specific kinetics of hydroxyl radical $(\mathrm{OH})$ with water $\left(\mathrm{H}_{2} \mathrm{O}\right)$ : Testing models of reactivity and atmospheric fractionation, J. Phys. Chem. A., 101, 1494-1500, doi:10.1021/jp962332p, 1997.

Fahey, K. M. and Pandis, S. N.: Size-resolved aqueousphase atmospheric chemistry in a three-dimensional chemical transport model, J. Geophys. Res., 108, 4690 doi:10.1029/2003JD003564, 2003.

Faloona, I.: Sulfur processing in the marine atmospheric boundary layer: A review and critical assessment of modeling uncertainties, Atmos. Environ., 43, 2841-2854, doi:10.1016/j.atmosenv.2009.02.043, 2009.

Faloona, I., Tan, D., Brune, W., Hurst, J., Barket, D., Couch, T. L., Shepson, P., Apel, E., Riemer, D., Thornberry, T., and Carroll, M. A.: Nighttime observations of anomalously high levels of hydroxyl radicals above a deciduous forest canopy, J. Geophys. Res.-Atmos., 106, 24315-24333, doi:10.1029/2000JD900691, 2001.

Fickert, S., Adams, J. W., and Crowley, J. N.: Activation of $\mathrm{Br}_{2}$ and $\mathrm{BrCl}$ via uptake of $\mathrm{HOBr}$ onto aqueous salt solutions, J. Geophys. Res., 104, 23719-23727, doi:10.1029/1999JD900359, 1999.

Fogelman, K. D., Walker, D. M., and Margerum, D. W.: Nonmetal redox kinetics: hypochlorite and hypochlorous acid reactions with sulfite, Inorg. Chem., 28, 986-993, doi:10.1021/ic00305a002, 1989.

Frenzel, A., Scheer, V., Sikorski, R., George, C., Behnke, W., and Zetzsch, C.: Heterogenerous Interconversion Reactions of $\mathrm{BrNO}_{2}, \mathrm{ClNO}_{2}, \mathrm{Br}_{2}$, and $\mathrm{Cl}_{2}$, J. Phys. Chem. A, 102, 1329 1337, doi:10.1021/jp973044b, 1998.

Geng, L., Schauer, A. J., Kunasek, S. A., Sofen, E. D., Erbland, J., Savarino, J., Allman, D. J., Sletten, R. S., and Alexander, B.: Analysis of oxygen-17 excess of nitrate and sulfate at submicromole levels using the pyrolysis method, Rapid Commun. Mass Sp., 27, 2411-2419, doi:10.1002/rcm.6703, 2013.

Gonfiantini, R., Stichler, W., and Rozanski, K.: Standards and intercomparison materials distributed by the International Atomic Energy Agency for stable isotope measurements, in: Reference and intercomparison materials for stable isotopes of light elements: Proceedings of a consultants meeting held in Vienna, 1-3 December 1993, IAEA-TECDOC-825, International Atomic Energy Agency, Vienna, 1993. 
González-Gaya, B., Zúñiga-Rival, J., Ojeda, M. J., Jiménez, B., and Dachs, J.: Field measurements of the atmospheric dry deposition fluxes and velocities of polycyclic aromatic hydrocarbons to the global oceans, Environ. Sci. Technol., 48, 5583-5592, doi:10.1021/es503490z, 2014.

Hanson, D. R. and Ravishankara, A. R.: The reaction probabilities of $\mathrm{ClONO}_{2}$ and $\mathrm{N}_{2} \mathrm{O}_{5}$ on 40 to $75 \%$ sulfuric acid solutions, J. Geophys. Res., 96, 17307-17314, doi:10.1029/91JD01750, 1991.

Harris, E., Sinha, B., van Pinxteren, D., Tilgner, A., Fomba, W., Schneider, J., Roth, A., Gnauk, T., Fahlbusch, B., Mertes, S., Lee, T., Collett, J., Foley, S., Borrmann, S., Hoppe, P., and Herrmann, H.: Enhanced role of transition metal ion catalysis during in-cloud oxidation of $\mathrm{SO}_{2}$, Science, 340, 727-730, doi:10.1126/science.1230911, 2013.

Harris, E., Sinha, B., van Pinxteren, D., Schneider, J., Poulain, L., Collett, J., D’Anna, B., Fahlbusch, B., Foley, S., Fomba, K. W., George, C., Gnauk, T., Henning, S., Lee, T., Mertes, S., Roth, A., Stratmann, F., Borrmann, S., Hoppe, P., and Herrmann, H.: In-cloud sulfate addition to single particles resolved with sulfur isotope analysis during HCCT-2010, Atmos. Chem. Phys., 14, 4219-4235, doi:10.5194/acp-14-4219-2014, 2014.

Haywood, J. and Boucher, O.: Estimates of the direct and indirect radiative forcing due to tropospheric aerosols: a review, Rev. Geophys., 38, 513-543, doi:10.1029/1999RG000078, 2000.

Hegg, D. A., Yuen, P.-F., and Larson, T. V.: Modeling the effects of heterogeneous cloud chemistry on the marine particle size distribution, J. Geophys. Res, 97, 12927-12933, doi:10.1029/92JD01184, 1992.

Hoffmann, M. R. and Calvert, J. G.: Chemical transformation modules for Eulerian acid deposition models, Volume II, The aqueous-phase chemistry, Tech. rep., NCAR, Box 3000, Boulder, CO 80307, 1985.

Holzwarth, G., Balmer, R. G., and Soni, L.: The fate of chlorine and chloramines in cooling towers Henry's law constants for flashoff, Water Res., 18, 1421-1427, doi:10.1016/0043-1354(84)900125, 1984 .

Huthwelker, T., Clegg, S. L., Peter, T., Carslaw, K., Luo, B. P., and Brimblecombe, P.: Solubility of $\mathrm{HOCl}$ in water and aqueous $\mathrm{H}_{2} \mathrm{SO}_{4}$ to stratospheric temperatures, J. Atmos. Chem., 21, 81-95, doi:10.1007/BF00712439, 1995.

Jauhiainen, J., Moore, J., Perämäki, P., Derome, J., and Derome, K.: Simple procedure for ion chromatographic determination of anions and cations at trace levels in ice core samples, Analytical Chimica Acta, 389, 21-29, doi:10.1016/S0003-2670(99)001853, 1999.

Jenkins, K. A. and Bao, H.: Multiple oxygen and sulfur isotope compositions of atmospheric sulfate in Baton Rouge, LA, USA, Atmos. Environ., 40, 4528-4537, doi:10.1016/j.atmosenv.2006.04.010, 2006.

Kerminen, V.-M., Petäjä, T., Manninen, H. E., Paasonen, P., Nieminen, T., Sipilä, M., Junninen, H., Ehn, M., Gagné, S., Laakso, L., Riipinen, I., Vehkamäki, H., Kurten, T., Ortega, I. K., Dal Maso, M., Brus, D., Hyvärinen, A., Lihavainen, H., Leppä, J., Lehtinen, K. E. J., Mirme, A., Mirme, S., Hõrrak, U., Berndt, T., Stratmann, F., Birmili, W., Wiedensohler, A., Metzger, A., Dommen, J., Baltensperger, U., Kiendler-Scharr, A., Mentel, T. F., Wildt, J., Winkler, P. M., Wagner, P. E., Petzold, A., Minikin, A., Plass-Dülmer, C., Pöschl, U., Laaksonen, A., and Kulmala,
M.: Atmospheric nucleation: highlights of the EUCAARI project and future directions, Atmos. Chem. Phys., 10, 10829-10848, doi:10.5194/acp-10-10829-2010, 2010.

Kettle, A., Andreae, M., Amouroux, D., Andreae, T., Bates, T., Berresheim, H., Bingemer, H., Boniforti, R., Curran, M., DiTullio, G., Helas, G., Jones, G., Keller, M., Kiene, R., Leck, C., Levasseur, M., Malin, G., Maspero, M., Matrai, P., McTaggart, A., Mihalopoulos, N., Nguyen, B., Novo, A., Putaud, J., Rapsomanikis, S., Roberts, G., Schebeske, G., Sharma, S., Simo, R., Staubes, R., Turner, S., and Uher, G.: A global database of sea surface dimethylsulfide (DMS) measurements and a procedure to predict sea surface DMS as a function of latitude, longitude, and month, Global Biogeochem. Cy., 13, 399-444, doi:10.1029/1999GB900004, 1999.

Kulmala, M., Pirjola, L., and Mäkelä, J. M.: Stable sulphate clusters as a source of new atmospheric particles, Nature, 404, 66-69, doi:10.1038/35003550, 2000.

Lawler, M. J., Sander, R., Carpenter, L. J., Lee, J. D., von Glasow, R., Sommariva, R., and Saltzman, E. S.: $\mathrm{HOCl}$ and $\mathrm{Cl}_{2}$ observations in marine air, Atmos. Chem. Phys., 11, 7617-7628, doi:10.5194/acp-11-7617-2011, 2011.

Lee, C. C.-W. and Thiemens, M. H.: The $\delta^{17} \mathrm{O}$ and $\delta^{18} \mathrm{O}$ measurements of atmospheric sulfate from a coastal and high alpine region: A mass-independent isotopic anomaly, J. Geophys. Res., 106, 17359-17373, doi:10.1029/2000JD900805, 2001.

Lee, C. C. W., Savarino, J. H., Cachier, H., and Thiemens, M. H.: Sulfur $\left({ }^{32} \mathrm{~S},{ }^{33} \mathrm{~S},{ }^{34} \mathrm{~S},{ }^{36} \mathrm{~S}\right)$ and oxygen $\left({ }^{16} \mathrm{O},{ }^{17} \mathrm{O},{ }^{18} \mathrm{O}\right)$ isotopic ratios of primary sulfate produced from combustion processes, Tellus B, 54, 193-200, doi:10.1034/j.1600-0889.2002.01384.x, 2002.

Lee, C. C. W., Savarino, J., and Thiemens, M. H.: Mass independent oxygen isotopic composition of atmospheric sulfate: Origin and implications for the present and past atmospheres of Earth and Mars, Geophys. Res. Lett., 28, 1783-1786, doi:10.1029/2000GL011826, 2001.

Lelieveld, J. and Heintzenberg, J.: Sulfate cooling effect on climate through in-cloud oxidation of anthropogenic $\mathrm{SO}_{2}$, Science, 258, 117-120, doi:10.1126/science.258.5079.117, 1992.

Liao, J., Huey, L. G., Tanner, D. J., Flocke, F. M., Orlando, J. J., Neuman, J. A., Nowak, J. B., Weinheimer, A. J., Hall, S. R., Smith, J. N., Fried, A., Staebler, R. M., Wang, Y., Koo, J.-H., Cantrell, C. A., Weibring, P., Walega, J., Knapp, D. J., Shepson, P. B., and Stephens, C. R.: Observations of inorganic bromine $\left(\mathrm{HOBr}, \mathrm{BrO}\right.$, and $\left.\mathrm{Br}_{2}\right)$ speciation at Barrow, Alaska, in spring 2009, J. Geophys. Res., 117, D00R16, doi:10.1029/2011JD016641, 2012.

Liu, Q.: Kinetics of aqueous phase reactions related to ozone depletion in the arctic troposphere: bromine chloride hydrolysis, bromide ion with ozone, and sulfur(IV) with bromine and hypobromous acid, $\mathrm{PhD}$ thesis, Department of Chemistry, Purdue University, USA, 253 pp., 2000.

Lu, K. D., Rohrer, F., Holland, F., Fuchs, H., Brauers, T., Oebel, A., Dlugi, R., Hu, M., Li, X., Lou, S. R., Shao, M., Zhu, T., Wahner, A., Zhang, Y. H., and Hofzumahaus, A.: Nighttime observation and chemistry of HOx in the Pearl River Delta and Beijing in summer 2006, Atmos. Chem. Phys., 14, 4979-4999, doi:10.5194/acp-14-4979-2014, 2014. 
Lyons, J. R.: Transfer of mass-independent fractioation on ozone to other oxygen-containing molecules in the atmosphere, Geophys. Res. Lett., 28, 3231-3234, doi:10.1029/2000GL012791, 2001.

Mauldin III, R. L., Berndt, T., Sipilä, M., Paasonen, P., Petäjä, T., Kim, S., Kurtén, T., Stratmann, F., Kerminen, V.-M., and Kulmala, M.: A new atmospherically relevant oxidant of sulphur dioxide, Nature, 488, 193-196, doi:10.1038/nature11278, 2012.

McCabe, J. R., Savarino, J., Alexander, B., Gong, S., and Thiemens, M. H.: Isotopic constraints on non-photochemical sulfate production in the Arctic winter, Geophys. Res. Lett., 33, L05810, doi:10.1029/2005GL025164, 2006.

McCoy, W. F., Blatchley III, E. R., and Johnson, R. W.: Hypohalous acid and haloamine flash off in industrial evaporative cooling systems, Technical paper number TP90-09, Cooling Tower Institute 1990 annual meeting, Cooling Technology Institute, Houston, TX, 1990.

Millero, F. J., Feistel, R., Wright, D. G., and McDougall, T. J.: The composition of Standard Seawater and the definition of the Reference-Composition Salinity Scale, Deep-Sea Res. Pt. I, 55, 50-72, doi:10.1016/j.dsr.2007.10.001, 2008.

Myhre, G., Shindell, D., Bréon, F.-M., Collins, W., Fuglestvedt, J., Huang, J., Koch, D., Lamarque, J.-F., Lee, D., Mendoza, B., Nakajima, T., Robock, A., Stephens, G., Takemura, T., and Zhang, H.: Anthropogenic and Natural Radiative Forcing, in: Climate Change 2013: The Physical Science Basis. Contribution of Working Group I to the Fifth Assessment Report of the Intergovernmental Panel on Climate Change, edited by: Stocker, T. F., Qin, D., Plattner, G.-K., Tignor, M., Allen, S. K., Boschung, J., Nauels, A., Xia, Y., Bex, V., and Midgley, P. M., Cambridge University Press, Cambridge, UK, New York, NY, USA, 2013.

Neuman, J. A., Nowak, J. B., Huey, L. G., Burkholder, J. B., Dibb, J. E., Holloway, J. S., Liao, J., Peischl, J., Roberts, J. M., Ryerson, T. B., Scheuer, E., Stark, H., Stickel, R. E., Tanner, D. J., and Weinheimer, A.: Bromine measurements in ozone depleted air over the Arctic Ocean, Atmos. Chem. Phys., 10, 6503-6514, doi:10.5194/acp-10-6503-2010, 2010.

O’Dowd, C. D., Lowe, J. A., Clegg, N., Smith, M. H., and Clegg, S. L.: Modeling heterogeneous sulphate formation in maritime stratiform clouds, J. Geophys. Res., 105, 7143-7160, doi:10.1029/1999JD900915, 2000.

Olivier, J. G. J. and Berdowski, J. J. M.: Global emissions sources and sinks, in: The Climate System, edited by: Berdowski, J., Guicherit, R., and Heij, B. J., A. A. Balkema Publishers/Swets \& Zeitlinger Publishers, Lisse, the Netherlands, 33-78, 2001.

Park, R. J., Jacob, D. J., Field, B. D., Yantosca, R. M., and Chin, M.: Natural and transboundary pollution influences on sulfate-nitrate-ammonium aerosols in the United States: implications for policy, J. Geophys. Res., 109, D15204, doi:10.1029/2003JD004473, 2004.

Patris, N., Cliff, S. S., Quinn, P. K., Kasem, M., and Thiemens, M. H.: Isotopic analysis of aerosol sulfate and nitrate during ITCT-2k2: Determination of different formation pathways as a function of particle size, J. Geophys. Res.-Atmos., 112, D23301, doi:10.1029/2005JD006214, 2007.

Pierce, J. R., Evans, M. J., Scott, C. E., D'Andrea, S. D., Farmer, D. K., Swietlicki, E., and Spracklen, D. V.: Weak global sensitivity of cloud condensation nuclei and the aerosol indirect effect to Criegee $+\mathrm{SO}_{2}$ chemistry, Atmos. Chem. Phys., 13, 3163-3176, doi:10.5194/acp-13-3163-2013, 2013.
Roelofs, G. J. H.: A cloud chemistry sensitivity study and comparison of explicit and bulk cloud model performance, Atmos. Environ. A-Gen., 27, 2255-2264, doi:10.1016/0960-1686(93)90396G, 1993.

Sander, R.: Compilation of Henry's law constants (version 4.0) for water as solvent, Atmos. Chem. Phys., 15, 4399-4981, doi:10.5194/acp-15-4399-2015, 2015.

Sander, S. P., Friedl, R. R., Golden, D. M., Kurylo, M. J., Moortgat, G. K., Keller Rudek, H., Wine, P. H., Ravishankara, A. R., Kolb, C. E., Molina, M. J., Finlayson-Pitts, B. J., Huie, R. E., and Orkin, V. L.: Chemical Kinetics and Photochemical Data for Use in Atmospheric Studies, Evaluation Number 15, JPL Publication 06-2, Jet Propulsion Laboratory, Pasadena, CA, available at: http://jpldataeval.jpl.nasa.gov (last access: 25 March 2016), 2006.

Savarino, J. and Thiemens, M. H.: Analytical procedure to determine both $\delta^{18} \mathrm{O}$ and $\delta^{17} \mathrm{O}$ of $\mathrm{H}_{2} \mathrm{O}_{2}$ in natural water and first measurements, Atmos. Environ., 33, 3683-3690, doi:10.1016/S1352-2310(99)00122-3, 1999.

Savarino, J., Lee, C. C. W., and Thiemens, M. H.: Laboratory oxygen isotopic study of sulfur (IV) oxidation: Origin of the massindependent isotopic anomaly in atmospheric sulfates and sulfate mineral deposits on Earth, J. Geophys. Res., 105, 29079-29088, doi:10.1029/2000JD900456, 2000.

Schmidt, J. A., Jacob, D. J., Horowitz, H. M., Hu, L., Sherwen, T., Evans, M. J., Liang, Q., Suleiman, R. M., Oram, D. E., Le Breton, M., Percival, C. J., Wang, S., Dix, B., and Volkamer, R.: Modeling the observed tropospheric BrO background: Importance of multiphase chemistry and implications for ozone, $\mathrm{OH}$, and mercury, J. Geophys. Res.-Atmos., in review, 2016.

Sievering, H., Boatman, J., Galloway, J., Keene, W., Kim, Y., Luria, M., and Ray, J.: Heterogeneous sulfur conversion in sea-salt aerosol particles: the role of aerosol water content and size distribution, Atmos. Environ. A-Gen., 25, 1479-1487, doi:10.1016/0960-1686(91)90007-T, 1991.

Sievering, H., Cainey, J., Harvey, M., McGregor, J., Nichol, S., and Quinn, P.: Aerosol non-sea-salt sulphate in the remote marine boundary layer under clear-sky and normal cloudiness conditions: Ocean-derived biogenic alkalinity enhances sea- salt sulfate production by ozone oxidation, J. Geophys. Res., 109, D19317, doi:10.1029/2003JD004315, 2004.

Sofen, E. D., Alexander, B., and Kunasek, S. A.: The impact of anthropogenic emissions on atmospheric sulfate production pathways, oxidants, and ice core $\Delta^{17} \mathrm{O}\left(\mathrm{SO}_{4}^{2-}\right)$, Atmos. Chem. Phys., 11, 3565-3578, doi:10.5194/acp-11-3565-2011, 2011.

Stockwell, W. R. and Calvert, J. G.: The mechanism of the $\mathrm{HO}-\mathrm{SO}_{2}$ reaction, Atmos. Environ., 17, 2231-2235, doi:10.1016/00046981(83)90220-2, 1983.

Streets, D. G., Zhang, Q., Wang, L., He, K., Hao, J., Wu, Y., Tang, Y., and Carmichael, G. R.: Revisiting China's CO emissions after the Transport and Chemical Evolution over the Pacific (TRACE-P) mission: Synthesis of inventories, atmospheric modeling, and observations, J. Geophys. Res., 111, D14306, doi:10.1029/2006JD007118, 2006.

Troy, R. C. and Margerum, D. W.: Non-metal redox kinetics: Hypobromite and hypobromous acid reactions with iodide and with sulfite and the hydrolysis of bromosulfate, Inorg. Chem., 30, 3538-3543, doi:10.1021/ic00018a028, 1991. 
Vestreng, V. and Klein, H.: Emission data reported to UNECE/EMEP: Quality insurance and trend analysis \& Presentation of WebDab, MSC-W Status Report, Tech. rep., Norwegian Meteorological Institute, Oslo, Norway, http://www.emep.int/publ/ reports/2002/mscwnote12002.pdf, 2002.

Vicars, W. C. and Savarino, J.: Quantitative constraints on the ${ }^{17} \mathrm{O}$-excess $\left(\Delta^{17} \mathrm{O}\right)$ signature of surface ozone: Ambient measurements from $50^{\circ} \mathrm{N}$ to $50^{\circ} \mathrm{S}$ using the nitrite-coated filter technique, Geochim. Cosmochim. Acta, 135, 270-287, doi:10.1016/j.gca.2014.03.023, 2014.

Vogt, R., Crutzen, P. J., and Sander, R.: A mechanism for halogen release from sea-salt aerosol in the remote marine boundary layer, Nature, 383, 327-330, doi:10.1038/383327a0, 1996.

van Donkelaar, A., Martin, R. V., Pasch, A. N., Szykman, J. J., Zhang, L., Wang, Y. X., and Chen, D.: Improving the accuracy of daily satellite-derived ground-level fine aerosol concentration estimates for North America, Environ. Sci. Technol., 46, 1197111978, doi:10.1021/es3025319, 2012. von Glasow, R., Sander, R., Bott, A., and Crutzen, P. J.: Modeling halogen chemistry in the marine boundary layer, 2 . Interactions with sulfur and the cloud-covered MBL, J. Geophys. Res., 107, 4323, doi:10.1029/2001JD000943, 2002.

Yiin, B. S. and Margerum, D. W.: Kinetics of Hydrolysis of the Chlorosulfate Ion, Inorg. Chem., 27, 1670-1672, doi:10.1021/ic00283a002, 1988.

Yuen, P.-F., Hegg, D. A., Larson, T. V., and Barth, M. C.: Paramerization of heterogeneous droplet chemistry for use in bulk cloud models, J. Appl. Meteorol., 35, 679-689, doi:10.1175/15200450(1996)035<0679:POHDCF>2.0.CO;2, 1996. 